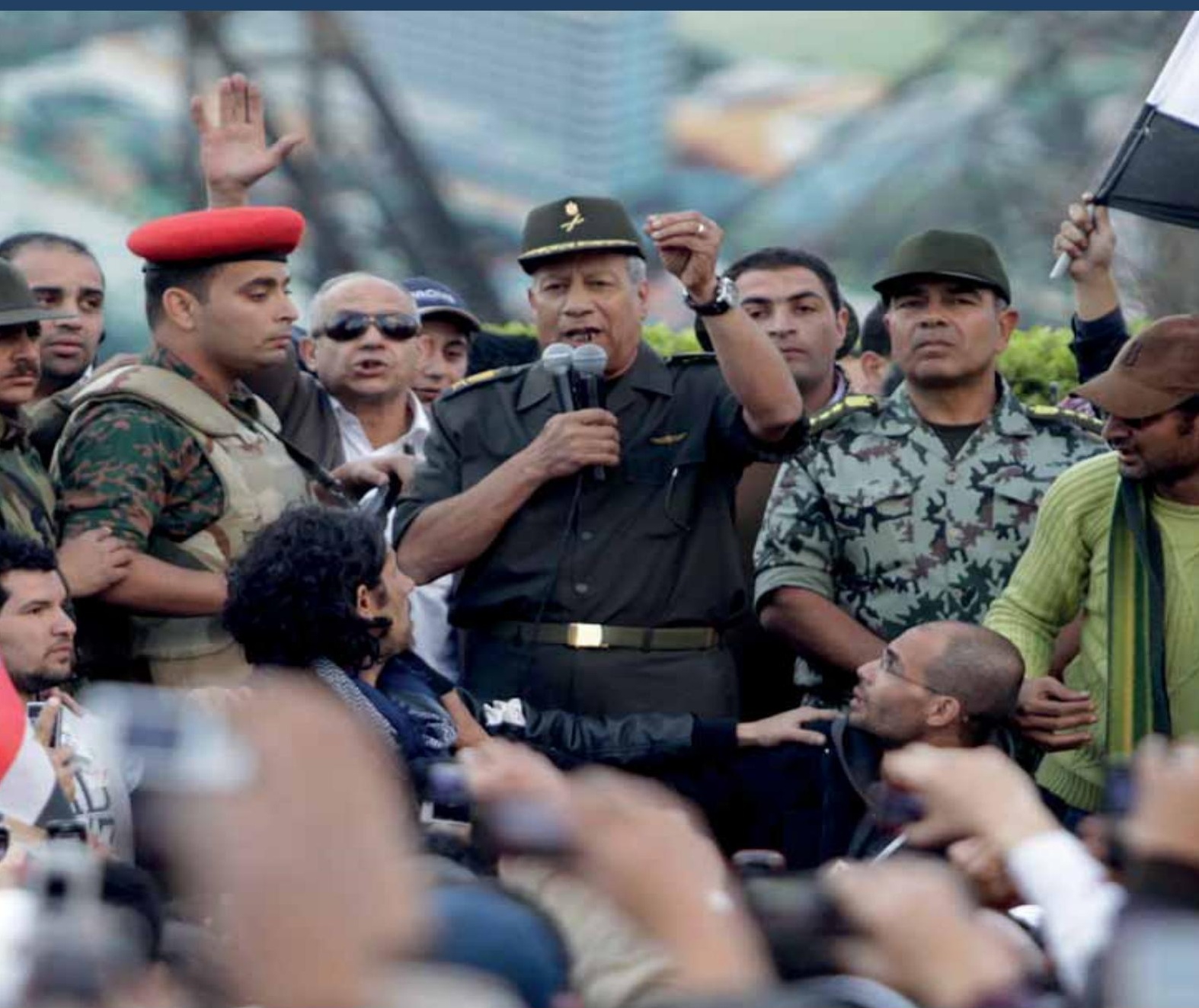

Arab Uprisings and Armed Forces: Between Openness and Resistance

Derek Lutterbeck 
SSR PAPER 2

\section{Arab Uprisings and Armed Forces Between Openness and Resistance}

Derek Lutterbeck 
Published by

Ubiquity Press Ltd.

6 Osborn Street, Unit 2N

London E1 6TD

www.ubiquitypress.com

Text (C) Derek Lutterbeck 2011

First published 2011

Transferred to Ubiquity Press 2018

Cover image (C) Suhaib Salem/Reuters

Editors: Alan Bryden \& Heiner Hänggi

Production: Yury Korobovsky

Copy editor: Cherry Ekins

ISBN (PDF): 978-1-911529-29-3

ISSN (online): 2571-9297

DOI: https://doi.org/10.5334/bbm

This work is licensed under the Creative Commons Attribution 4.0 International License (unless stated otherwise within the content of the work). To view a copy of this license, visit http://creativecommons. org/licenses/by/4.0/ or send a letter to Creative Commons, 444 Castro Street, Suite 900, Mountain View, California, 94041, USA. This license allows for copying any part of the work for personal and commercial use, providing author attribution is clearly stated.

This book was originally published by the Geneva Centre for the Democratic Control of Armed Forces (DCAF), an international foundation whose mission is to assist the international community in pursuing good governance and reform of the security sector. The title transferred to Ubiquity Press when the series moved to an open access platform. The full text of this book was peer reviewed according to the original publisher's policy at the time. The original ISBN for this title was 978-92-9222-180-5.

SSR Papers is a flagship DCAF publication series intended to contribute innovative thinking on important themes and approaches relating to security sector reform (SSR) in the broader context of security sector governance (SSG). Papers provide original and provocative analysis on topics that are directly linked to the challenges of a governance-driven security sector reform agenda. SSR Papers are intended for researchers, policy-makers and practitioners involved in this field.

The views expressed are those of the author(s) alone and do not in any way reflect the views of the institutions referred to or represented within this paper.

Suggested citation:

Lutterbeck, D. 2018. Arab Uprisings and Armed Forces: Between Openness and Resistance. London: Ubiquity Press. DOI: https://doi.org/10.5334/bbm. License: CC-BY 4.0 


\section{Contents}

$\begin{array}{ll}\text { Introduction } & 5\end{array}$

Civil-military relations $\quad 8$

The concept of civil-military relations 8

Civil-military relations in the Middle East and North Africa 11

Institutionalisation versus patrimonialism 13

Conscript versus professional army 15

Framework of analysis 17

Openness to pro-reform movements

Tunisia 20

Egypt 24

Fracturing of the armed forces

Libya 31

Yemen 36

Crackdown on pro-reform movements

Bahrain 41

Syria 44

Conclusion

Arab uprisings and armed forces: Comparative perspective 52

Towards democratic civil-military relations? 54 



\section{INTRODUCTION}

Since late 2010 an unprecedented wave of popular uprisings calling for greater political freedoms, and in several countries even regime change, has swept across much of the Arab world. Following the Tunisian revolution in January 2011, which led to the toppling of the country's long-standing autocrat, Zine al-Abidine Ben Ali, protest movements gained momentum in Egypt, where the country's president for almost 30 years, Hosni Mubarak, stepped down after some three weeks of massive anti-regime demonstrations. In Libya, Colonel Muammar Qaddafi, who had ruled since 1967, was removed from power (and subsequently killed) after a sixmonths-long civil war between his regime and rebel fighters opposed to his rule. In countries such as Bahrain, Syria and Yemen, seemingly wellestablished leaders have also appeared increasingly shaky in the face of growing opposition movements calling for both greater political freedoms and an end to the regimes in power.

A key role in these Arab revolutions has been played by the armed forces of the countries experiencing such upheavals. While all Arab regimes facing challenges from pro-democracy movements have called upon their militaries to confront these popular uprisings, the armed forces have responded quite differently across the region, ranging from openness to, and even support for, protest movements to internal fracturing or firm support for the regime in power. This paper seeks to explain these different responses by focusing on the nature of civil-military relations and the characteristics of the military apparatus of Arab countries. The main argument advanced here is that the divergent responses of armed forces to the popular uprisings can be explained by two main factors: the degree of 
institutionalisation of the armed forces, and their relationship to society at large. The more institutionalised the military apparatus is, and the stronger its linkage to society, the more open it has been to pro-reform movements. Conversely, in countries where the armed forces are characterised by a low level of institutionalisation and a weak relationship to the population at large, they have been opposed to anti-regime uprisings.

While a number of analyses and discussions of the current revolutions in the Middle East and North Africa have focused on the origins (and nature) of the popular uprisings, such as the widespread dissatisfaction with economic mismanagement and political oppression, the responses of the regimes and their armed forces to the protest movements have thus far not received much attention, at least not in a comparative perspective. As one commentator has put it, the overwhelming focus thus far has been on the 'demand side' of the revolutions, whereas the 'supply side' $-i$.e. the response of the regimes and their coercive apparatus - has been somewhat neglected. ${ }^{1}$ Needless to say, the success of any popular uprising will ultimately be dependent on both factors: the size and strength of the uprising itself, and the ability and willingness of the regime and its security forces to suppress the pro-reform movement. ${ }^{2}$

In explaining armed forces' attitudes and actions towards anti-regime movements with reference to the characteristics of the military apparatus of Arab countries, it could be argued that this paper overlooks another potentially important factor: external pressures on the regimes - or even the militaries themselves - in favour of (or against) the popular uprisings. It can hardly be denied that external factors have been a significant element in the current upheavals in the Middle East and North Africa. Western countries, in particular, have generally been rather quick to express their support for the pro-democracy movements and condemn the regimes' crackdown on the popular uprisings. ${ }^{3}$ Moreover, against the regimes of both Libya and Syria sanctions have been enacted, and in Libya Western (as well as some other) countries have even taken military action against the Qaddafi regime with the official mandate to protect the civilian population. However, while these external pressures have certainly been relevant, the argument made here is that the nature of civil-military relations can in itself explain armed forces' responses to the popular uprisings. In other words, the armed forces of Arab countries have reacted to pro-reform movements 
in ways which the specific form of civil-military relations in the respective countries would lead us to expect, regardless of external factors.

Finally, it should be noted that this paper does not cover the actions of the entire coercive apparatus or security sector of Arab countries during the current upheavals. Rather, its focus is confined to one element of these countries' security forces, i.e. the armed forces, although the distinction between these and other security forces might not always be clear-cut. This is not to argue that other security bodies, such as internal security forces or intelligence agencies, have not also played a significant part in responding to - and in particular suppressing - the popular uprisings in the countries of the region. However, as subsequent sections will argue, the armed forces have certainly been key actors in this regard, thus meriting separate analysis of their role in the Arab revolutions.

This paper is structured as follows. The next section sets out the analytical framework which underpins the empirical case studies. The sections that follow comprise case studies of six Arab countries which have experienced large-scale pro-democracy and anti-regime movements but where the armed forces' response to these uprisings has varied significantly: Tunisia, Egypt, Libya, Yemen, Bahrain and Syria. The last section summarises the main findings of the six cases in comparative perspective and, based on this, discusses the prospects of establishing more democratic civil-military relations in the countries of the Middle East and North Africa.

The methodology followed in this paper is a comparative case study approach, as developed by Arend Lijphart and others. ${ }^{4}$ While not allowing for statistical analyses and testing, such a method nevertheless makes it possible to identify and explain similarities and differences among broadly comparable cases. More specifically, this paper uses a 'most similar' case study design which aims to explain differences (in the dependent variable) between otherwise similar cases. The aim of the paper is to explain differences in armed forces' responses to anti-regime movements (dependent variable) with reference to different forms of civil-military relations (independent variable) in countries which have all experienced large-scale popular uprisings, and are thus (largely) similar in this respect. ${ }^{5}$ 


\section{CIVIL-MILITARY RELATIONS}

The aim of this section is to set out the analytical framework of the paper. The framework is derived from theories of civil-military relations in general, as well as regarding the Middle East and North Africa more specifically. It begins with a brief discussion of some of the major contributions to civilmilitary relations as an academic discipline. It then provides an overview of the literature on civil-military relations in the Middle East and North Africa more specifically, including some typologies which have been suggested in this context. The analytical framework is based on two main factors which are assumed to influence armed forces' responses to pro-reform movements: the armed forces' degree of institutionalisation or patrimonialism, and the strength or weakness of their relationship to society at large. Particular emphasis is placed in this study on the first factor.

\section{The concept of civil-military relations}

As an area of study, civil-military relations is generally concerned with the relationship between the military and the civilian authorities, or in a broader sense between the military and society as a whole. Most analyses in this field subscribe to the normative assumption that civilian (and democratic) control of the military is preferable to the absence of such control. In other words, the military should be subject and accountable to 
the (democratically elected) civilian authorities, whereas the latter should be free from interference by the military in exercising political power.

While civilian control and non-interference of the military in politics are seen as a desirable state of affairs, there has been some disagreement among analysts as to how this is best achieved. Two main schools of thought, represented by Samuel Huntington on the one hand and Morris Janowitz on the other, can be distinguished in this context. According to Huntington, the development of a distinct form of 'military professionalism' is the best way to ensure civilian control of the military. Focusing in particular on the officer corps, Huntington has argued that 'military professionalism' implies a specific expertise in the use of force, a primary responsibility within the state for military functions and the existence of a bureaucratic military organisation with its own internal hierarchy and rules of advancement. If the officer corps is recognised by the state and society as a distinct body of experts which is seen as competent and as primarily responsible for military tasks, and which is free from direct interference from the civilian world, the military would, according to Huntington, be willing to submit itself to the civilian authorities. In other words, it is through the development of a distinct and relatively independent professional category of soldier and officer, and thus of military professionalism, that the military will become politically neutral. ${ }^{6}$

A somewhat different - and to some extent even opposite - path towards ensuring civilian control of the military has been suggested by Janowitz. Like Huntington, Janowitz highlighted the fundamental difference between the military and civilian spheres, with the former based on hierarchy, order and strict discipline, while the latter is disorderly and values individual freedoms. However, in contrast to Huntington, Janowitz did not advocate separation between the military and civilian realms in order to achieve civilian control of the military, but rather 'convergence' between the two. According to Janowitz, the best way to make sure that the military remains responsive to the demands of the civilian authorities is to encourage mutual exchange and regular interaction between the two domains. This would ensure that the values and expectations of society remain present within the military establishment. For this reason, Janowitz was a supporter of general conscription, which he saw as a key instrument in ensuring a convergence between the military and civilian spheres. 
Conscription, in his view, would lead to a 'civilianisation' of the military, and thus prevent undue military interference in politics. ${ }^{7}$

While Huntington's and Janowitz's theories of civil-military relations were derived mainly from the experiences of the United States and other developed countries, a number of other analysts have focused on the specific nature of civil-military relations in less developed countries. These analyses have generally highlighted the greater political role played by the military in many developing states and its frequent intervention in politics, for example in the form of military coups. Arguably the first major contribution in this context was Samuel F. Finer's Man on Horseback. According to Finer, military intervention in politics is generally more likely and more extensive in countries of what he called 'low political culture', as opposed to countries with a 'developed political culture'. Political culture, in Finer's analysis, refers to the existence of functioning state institutions and procedures regulating the exercise a political power. In countries with 'low political culture', such institutions and procedures either do not exist or lack popular legitimacy. It is under such circumstances that military intervention into politics is likely and, when it happens, more intense and far-reaching than in countries with functioning state institutions. According to Finer, such intervention may also occur in countries with 'high' political culture, but is usually limited to the exercise of pressure by the military on the political leadership. In countries with 'low' political culture, by contrast, military interference may involve the removal of the civilian government, or even its replacement by a military regime. ${ }^{8}$

While most analyses of the political role of the military in developing countries have highlighted the absence of functioning and legitimate state institutions as a key factor in prompting military intervention into politics, other factors have also been identified. Some analysts have suggested, for example, that in those developing countries where the military was at the forefront in the struggle for independence and subsequent state creation, its political influence has often lasted into the post-independence period a phenomenon which has been referred to as the 'birth-right principle'. 9 Algeria is one example where the armed forces played a crucial part in the country's struggle for independence from France, and this has continued to legitimise its predominant role in the Algerian political system up to the present day. 
Other analysts have looked at the social conditions which might be conducive to a strong military role in politics. Amos Perlmutter, for instance, identified several social conditions which, in his view, contribute to what he called 'praetorianism', i.e. a state in which political decisionmaking is controlled or at least heavily influenced by the military. These include a lack of social cohesion, the existence of fratricidal social classes, in particular a politically weak middle class, and a generally low level of political mobilisation, all of which according to Perlmutter provide a fertile ground for military interference in politics. ${ }^{10}$

\section{Civil-military relations in the Middle East and North Africa}

Turning to the Middle East and North Africa more specifically, it can be noted that the 1960s and 1970s witnessed the emergence of a significant body of literature on the political influence of the military in Middle Eastern states, although interest in the topic somewhat declined in subsequent years. ${ }^{11}$ Given the frequency of military coups and other forms of military intervention into politics in the countries of the region, academic interest in the topic is of course hardly surprising. Key themes in this earlier literature were the nature and patterns of military coups, the social background and outlook of the military officers who took power in these states and the nature of the military-dominated regimes which resulted from military interventions into politics. ${ }^{12}$

When it comes to the characteristics of military-based regimes in the Middle East and North Africa, a commonly referred to distinction has been the one between military 'ruler' and military 'arbitrator' regimes, as developed by Amos Perlmutter. The two concepts basically refer to different degrees of intensity and length of military intervention in politics. According to Perlmutter, a military 'ruler' regime is one where the military takes direct control of political decision-making over extended periods of time, whereas in the military 'arbitrator' regime the military influences politics largely from the background, seeking to limit its involvement in politics in both time and intensity. ${ }^{13}$

Coming to the contemporary period, it can be argued that currently no Middle Eastern country qualifies as a military 'ruler' regime, where the military directly and openly controls political decision-making. Rather, most countries in the region can be described as military 'arbitrator' regimes, 
where most areas of policy-making are left to governments which are nowadays largely civilianised (even if they are often headed by former military leaders). Nevertheless, the armed forces remain key actors in overseeing the political process from behind the scenes. Moreover, in times of crisis or when core interests are threatened, the military is likely to grab the reins of power and take direct control of political decision-making. ${ }^{14}$ Indeed, in relative terms it can be argued that the Middle East and North Africa remains the region in the world where the armed forces continue to play the most important role in domestic politics. ${ }^{15}$ This strong internal role of the military has been seen by many analysts as one of the, if not the main, obstacles to political reforms and democratisation in the region. ${ }^{16}$

While most Middle Eastern states can thus be described at military arbitrator regimes, different types of civil-military relations can nevertheless be distinguished among the countries of the region. A useful typology in this context has been suggested by Mehran Kamrava, who identified three types of civil-military relations in the Middle East and North Africa: 'autocratic officer-politician' regimes, 'tribally dependent monarchies' and regimes with 'dual militaries'. ${ }^{17}$ The first type of regime is usually led by former military officers who, over time, have turned into civilian politicians. The state apparatus as a whole has also been largely civilianised, not least because the leaders have themselves become wary of the political power of the army. However, while the military is no longer directly involved in politics, it still plays an important role in the background, often through more informal channels. Countries such as Algeria, Egypt and Syria are examples of autocratic officer-politician regimes. In all of these states, the armed forces exercise political power through their symbiotic relationship with the all-powerful presidency. The military has held a de facto monopoly, or veto power, over the presidency, for which the armed forces remain the ultimate power base. ${ }^{18}$

A different form of civil-military relations can be found in the tribally based monarchies of the Arab world, such as the oil monarchies of the Gulf, or Morocco and Jordan. The distinguishing feature of these countries is their heavy reliance on either forces drawn from tribes which are particularly loyal to the regime or foreign mercenaries. The latter is the case in the small monarchies of the Gulf, such as Bahrain, Oman or Qatar, which due to their small size are not able to field large armies and are thus forced to rely to a considerable extent on foreign soldiers. In the larger 
monarchies, such as Saudi Arabia and Morocco, tribal loyalty is used to contain the influence of the regular army. In Saudi Arabia, for example, the National Guard, whose main task is to counterbalance the influence of the regular armed forces and protect the regime against internal challenges more generally, is drawn mainly from tribes particularly loyal to the royal family. ${ }^{19}$

Dual (or even multiple) military structures which are based less (or not only) on tribal loyalty but rather on ideology can also be found in a number of other countries of the region, such as Iran, Iraq (prior to 2003) and Libya under Qaddafi. In addition to a regular army, these states have created parallel militias whose primary task is to secure the regime in power against domestic threats, including challenges by the regular army. In contrast to the regular military, these militias are highly ideological and subject to constant indoctrination. They are usually made up of volunteers with strong ideological commitment and emotional attachment to the leader or regime, again in contrast to the - typically conscription-based regular army. ${ }^{20}$ The Iranian Revolutionary Guard is one example of such a highly ideological militia which views itself as the main guardian of the revolution of 1979.

\section{Institutionalisation versus patrimonialism}

What kind of responses to anti-regime protest movements can be expected from armed forces within the context of these different types of civilmilitary relations? Before answering this question, it is useful to consider an argument made by Eva Bellin, who has drawn on experiences with transformations from authoritarian and military-based to democratic rule in other parts of the world. She suggested that the degree of 'institutionalisation' of the security apparatus is a key factor in determining its reaction to pro-reform movements: 'The more institutionalized the security establishment is, the more willing it will be to disengage from power and allow political reform to proceed. The less institutionalized it is, the less amenable it will be to reform. ${ }^{21}$ Institutionalisation in this context refers to the fact that the armed forces, or the security apparatus more generally, are rule-bound and based on meritocratic principles. They are governed by a clear set of rules, have established career paths and promotion is based on performance rather than on political or other 
loyalties. There is also a clear separation between the private and public realms, to counteract corruption and security forces' predatory behaviour against society. If the armed forces are based on such principles, this usually implies a commitment of the military to the country's national interest as a whole, as opposed to serving the interests of individual officers or military leaders. Ultimately, and crucially, this also means that the armed forces have an identity and legitimacy which are distinct from the regime in power. $^{22}$

The opposite of institutionalisation, in Bellin's analysis, is 'patrimonialism', meaning that the security apparatus is characterised by political favouritism and cronyism. Internal hierarchy and advancement within the security establishment are determined by political or ideological loyalties, as opposed to military or other professional competence. There is also a blurring between the private and public domains, and security agencies are characterised by a high level of favouritism and corruption. The reason why a military or security apparatus based on patrimonialism is more likely to oppose political reforms and regime change is that its role and status are closely tied to the regime, so it has more to lose from such reforms. By contrast, institutionalisation in the sense described above will engender greater tolerance for reform and political change because the security apparatus has an identity and legitimacy which are separate from the regime in power. If the armed forces or other elements of the coercive apparatus are highly institutionalised, they can expect to continue to exist and maintain their status even after a change in regime. ${ }^{23}$

Coming back to Kamrava's typology of civil-military relations in the Middle East and North Africa, it can be argued that the degree of institutionalisation, and thus the willingness to accept political reform or even regime change, is likely to be low in the case of both tribally based and ideological security forces. As mentioned previously, such forces are based mainly on tribal or ideological loyalty to the regime and its leaders, as opposed to professional competence and other meritocratic principles. Having little or no legitimacy outside the regime in power, and owing their status (or even their existence) solely to the leaders they serve, such forces are likely to be opposed to pro-reform movements. In the case of autocratic officer-politician regimes it is more difficult to make generalisations, as the level of institutionalisation of the security apparatus and thus its openness to political reforms might vary considerably from one country to the next. 
In general, it can be assumed that in comparison to predominantly tribally based or ideological forces, armed forces in autocratic officer-politician regimes tend to be characterised by a higher level of institutionalisation, but their institutionalisation, and thus openness to reforms, might nevertheless be low as a result of other patrimonial characteristics (in the sense described above), such as large-scale cronyism or corruption, or other forms of politicisation of the armed forces.

While a low level of institutionalisation, or high degree of patrimonialism, of the military is generally likely to engender resistance to pro-reform movements, if the degree of institutionalisation is extremely low this might also have another effect (which was not envisaged by Bellin): a fracturing of the armed forces. If, for example, the armed forces are dominated entirely by personal allegiances to individual military commanders, as opposed to the institution as a whole, or if the military is composed of multiple and (largely) disconnected forces and is thus highly fragmented, the challenge of pro-reform movements might lead to a splintering of the military. An analogy can be drawn to states: in the same way that states which lack coherent and cohesive institutions are prone to fracturing (and civil war) when confronted with serious domestic challenges, so are armed forces which lack any level of institutionalisation and cohesiveness likely to break up when facing a large-scale popular uprising. Indeed, as discussed below, in some Arab countries the challenges from pro-reform movements have resulted in such a fracturing of the military: usually the most elite units have remained loyal to the regime whereas others have sided with the protesters. At least in part, the splintering of the military apparatus in these cases can be explained by the extremely low level of institutionalisation of the armed forces in the sense defined above.

\section{Conscript versus professional army}

While the degree of institutionalisation/patrimonialism goes some way to explain armed forces' responses to recent pro-reform movements in the Middle East and North Africa, it is suggested here that at least one other factor needs to be taken into account: the strength or weakness of the armed forces' relationship to the population at large. The main limitation of Bellin's concepts of institutionalisation/patrimonialism is the fact that they 
essentially focus on the connection between the security establishment and the regime. What is missing from this picture is the relationship between the security forces and society, which is also likely to shape a military force's response to a popular uprising. It can be assumed that if there is a strong organic link between the armed forces and the population, it is less likely that they will use force against protests which are supported by large segments of the population. Within the typologies described above, it can be argued that in countries which rely heavily on foreign soldiers (such as the small monarchies of the Gulf), or where security forces are drawn primarily from certain tribes which are close to the regime, there will be fewer inhibitions in using force against a popular uprising. Conversely, if the armed forces are firmly anchored in society at large, they are likely to be (more) reluctant to use force against the country's population, as they will more easily identify with the demands of the protesters.

While there are of course various ways in which the military might be linked to society, arguably the most important mechanism which states have used to ensure a strong linkage between the army and the population is general or broad-based conscription. ${ }^{24}$ Indeed, looking at major popular uprisings over the last ten years, there is at least prima facie evidence of a relationship between their success or failure and the use of general conscription. Table 1 lists eight major uprisings which have occurred during

Table 1: Popular uprisings and conscript versus professional armies, 2000-2010

\begin{tabular}{|l|l|}
\hline \multicolumn{1}{|c|}{ Successful uprisings } & \multicolumn{1}{c|}{ Type of army } \\
\hline Serbia and Montenegro, 2000 ('Bulldozer Revolution') & Conscript army \\
\hline Georgia, 2003 ('Rose Revolution') & Conscript army \\
\hline Ukraine, 2005 ('Orange Revolution') & Conscript army \\
\hline Lebanon, 2005 ('Cedar Revolution') & Conscript army \\
\hline Kyrgyzstan, 2005 ('Tulip Revolution') & Conscript army \\
\hline Unsuccessful uprisings & Type of army \\
\hline Zimbabwe, 2008 & Professional army \\
\hline Iran, 2009 & \begin{tabular}{c} 
Professional army \\
\hline
\end{tabular} \\
\hline
\end{tabular}


the past ten years in different parts of the world. While it is beyond the scope of this paper to look at these revolutions in more detail, the table does suggest that popular uprisings stand a greater chance of success if there is a conscript army as opposed to a professional military force: all five countries which experienced successful revolutions had conscript armies, whereas the majority of those countries where popular uprisings have been suppressed had professional armies. The main exception seems to be Iran (2009), although the main instrument of repression used by the regime against the pro-reform movements was not the regular army but rather the Basij militia and the Revolutionary Guard, both of which are professional and voluntary forces.

\section{Framework of analysis}

Based on the preceding discussion, the analytical framework underpinning this study comprises two factors which are assumed to influence armed forces' response to pro-reform movements: their degree of institutionalisation or patrimonialism, and the strength or weakness of their relationship to society at large. While both of these factors are taken into account, particular emphasis is placed on the first one. Table 2 lists the different elements (indicators) used to measure these two variables.

A (highly) institutionalised military force is considered to be one which is (largely) based on meritocratic principles, is apolitical, free of cronyism and corruption, and broadly committed to serving the national interest. Ultimately, such a force will have an identity and legitimacy which are (relatively) distinct from the regime in power. Conversely, a patrimonial military force is one which is closely tied to the regime either through family, tribal or ideological ties or other forms of politicisation, and is characterised by a high degree of favouritism and corruption.

Turning to the second factor, the relationship between the military and the population is considered to be strong when the armed forces are based on general (or broad-based) conscription. The link is considered to be weak if the armed forces are drawn primarily from specific tribes or rely heavily on foreign soldiers.

The main argument of this paper is that the more institutionalised the armed forces are, and the more firmly they are anchored in the 
Table 2: Analytical framework: Security forces' characteristics contributing to resistance/openness to pro-reform movements

\begin{tabular}{|c|c|c|}
\hline $\begin{array}{l}\text { Resistance to pro-reform } \\
\text { movements }\end{array}$ & $\begin{array}{l}\text { Low level of } \\
\text { institutionalisation } \\
\text { - Security forces based on } \\
\text { tribal or family ties } \\
\text { - Ideological security forces } \\
\text { - Politicisation of security } \\
\text { forces } \\
\text { - Cronyism and corruption } \\
\text { in security forces }\end{array}$ & $\begin{array}{l}\text { Weak link to society } \\
\text { - Security forces drawn } \\
\text { mainly from specific } \\
\text { tribes } \\
\text { - Foreign mercenaries }\end{array}$ \\
\hline $\begin{array}{l}\text { Openness to pro-reform } \\
\text { movements }\end{array}$ & $\begin{array}{l}\text { High level of } \\
\text { institutionalisation } \\
\text { - Security forces based on } \\
\text { meritocratic principles } \\
\text { - Apolitical security forces } \\
\text { - Absence of cronyism and } \\
\text { corruption } \\
\text { - Commitment to national } \\
\text { interest }\end{array}$ & $\begin{array}{l}\text { Strong link to society } \\
\text { - Security forces based on } \\
\text { general (or broad-based) } \\
\text { conscription }\end{array}$ \\
\hline
\end{tabular}

population, the more open towards popular pro-reform or anti-regime movements they will be. Conversely, if the level of institutionalisation is low and the relationship to society weak, the military will be opposed to and seek to suppress pro-reform movements. It should be noted that the factors can potentially 'pull' in opposite directions, if for example the level of institutionalisation is low but there is strong linkage between the armed forces and society.

Moreover, the level of institutionalisation is considered to have an impact not only on the openness or resistance of the armed forces to proreform movements, but also on the extent to which the military will remain cohesive and united in the event of a popular uprising. If the degree of institutionalisation is extremely low, and the armed forces are not a coherent institution but rather are highly fragmented, it is unlikely that they will be able to maintain their unity when confronted with large-scale popular upheavals. In this case the military will be prone to splintering, possibly resulting in a civil war type of situation (Table 3 ).

In the following sections this framework will be applied to six Middle Eastern and North African countries which have experienced major popular 
Table 3: Level of institutionalisation of armed forces and responses to pro-reform movements

\begin{tabular}{|l|l|l|c|}
\hline $\begin{array}{l}\text { Level of } \\
\text { institutionalisation of } \\
\text { armed forces }\end{array}$ & High & Low & $\begin{array}{c}\text { Very low } \\
\text { (fragmented } \\
\text { armed forces) }\end{array}$ \\
\hline $\begin{array}{l}\text { Response to pro-reform } \\
\text { movements }\end{array}$ & Openness & Resistance & Fracturing \\
\hline
\end{tabular}

uprisings against the regimes in power, but where the armed forces have responded in different ways to these pro-reform movements. In Tunisia and Egypt the military (ultimately) sided with the protesters against the regime, or least its rulers, although more reluctantly in Egypt than in Tunisia. In Libya and Yemen the armed forces fractured when confronted with the uprising, with part of the military - typically the most elite units - showing fierce resistance against the pro-reform movements and other parts siding with the opposition. Finally, in Bahrain and Syria the military has violently suppressed the anti-regime uprising, and in so doing has (largely) maintained its unity, although in Syria there have been at least some defections. At the beginning of each case study an illustrative box containing a number of key facts and figures on the armed forces and the popular uprising in the respective country has been included. ${ }^{25}$ 


\section{OPENNESS TO PRO-REFORM MOVEMENTS}

An attitude of (relative) openness to the pro-reform movements, albeit to different degrees, was shown by the armed forces of Tunisia and Egypt. In both countries this can be explained by the (relatively) high level of institutionalisation of the armed forces and the close relationship between the military and society at large. In the same vein, the relatively more open approach towards, and even support for, the popular uprising by the Tunisian armed forces compared to their Egyptian counterparts can be accounted for by a higher degree of institutionalisation of the military in the case of Tunisia and a weaker relationship between the armed forces and the regime.

\section{Tunisia}

Tunisia was the first Arab country to experience a widespread popular upheaval against the regime, which saw its long-standing ruler, Zine alAbidine Ben Ali, toppled after several weeks of massive anti-government demonstrations. The Tunisian armed forces played a key role in the downfall of Ben Ali, and their response to the pro-reform movement can be explained by the specific nature of civil-military relations in Tunisia. While in Kamrava's terminology ${ }^{26}$ Tunisia (prior to the overthrow of the Ben Ali regime) can be described as an 'autocratic officer-politician' regime, the role and status of the armed forces in Tunisia has been quite unique in the Arab world. There is arguably no Arab country in which the identity of the 


\section{Tunisia: Key facts}

Population:

$10.4 \mathrm{~m}$

Size of armed forces:

35,000

Military expenditure:

US\$540 m

As percentage of GDP

$1.5 \%$

Conscription:

Yes

Beginning of protests:

17 Dec 2010

Toppling of leader:

Yes

(14 Jan 2011)

Estimated death toll:

armed forces has been more clearly distinct from the regime in power. Already at the moment of independence, the role of the Tunisian armed forces was different from most Arab countries: whereas the first post-independence leaders of many Arab countries came from the military, and the armed forces often formed the backbone of the postindependence regime, Tunisia's first leader, Habib Bourgiba, was a lawyer, and did not allow

a prominent political role for the military. As a convinced Francophile, Bourgiba sought to model Tunisia on French republican principles with a clear separation between political and military power. ${ }^{27}$

Even Bourgiba's successor, Ben Ali, although having the rank of general and coming to power through a (bloodless) coup, came from the intelligence services rather than the regular army. ${ }^{30}$ And once in power, Ben Ali also sought to limit the political influence of the armed forces as much as possible, not least out of fear of a (further) military takeover. Even though the Tunisian army has played some role in domestic matters, and has been deployed on several occasions within the country to quell internal unrest, since the late 1980s the overall evolution of the Tunisian armed forces has been characterised by its depoliticisation and professionalisation. ${ }^{31}$ This was done by forbidding any political activity by members of the armed forces and purging officers suspected of harbouring political ambitions. ${ }^{32}$ While reducing the army's political role, the main focus has been on enhancing its professional and technical expertise. As a result, the Tunisian military is nowadays widely perceived - at least by regional standards - as a highly professional and largely apolitical force which, in contrast to the Ben Ali regime itself, has been relatively free of corruption and cronyism. The often-used term la grande muette ('the big silent one') to describe the Tunisian armed forces highlights its discretion and non-interference in public affairs. 
Whereas the armed forces have been kept away from political power by the Tunisian leadership, Ben Ali relied first and foremost on the country's internal security and intelligence agencies as his power base and instrument for suppressing internal dissent. The regime's favouring of the internal security (and intelligence) apparatus over the armed forces was also manifest in sheer numbers: while the Tunisian armed forces count a total of only 35,000 soldiers, the country is estimated to have between 130,000 and 150,000 police officers. ${ }^{33}$ The Tunisian armed forces are by far the smallest in North Africa. Even Libya, whose population is less than half that of Tunisia, has armed forces more than double the size. Similarly, defence spending has been comparatively very low in Tunisia, amounting to around 1.5 per cent of GDP, well below practically any other country in the region.

The Tunisian military can thus be characterised as highly institutionalised in the sense defined above. It is a largely meritocratic and apolitical force with a rather weak relationship to the political leadership, and its identity and legitimacy have thus been largely independent of the Ben Ali regime. As for the relationship between the armed forces and society, it can be argued that this connection has been relatively strong, given that the Tunisian army is a conscript force. Moreover, most conscripts have been drawn from economically depressed areas and thus most likely shared the grievances which fuelled anti-regime demonstrations in Tunisia. ${ }^{34}$

As would be expected from a military apparatus displaying these characteristics, the Tunisian armed forces have from the outset shown openness to, and even support for, the popular uprising against the regime which erupted in December 2010. The event which sparked the upheaval was the self-immolation of the fruit vendor Mohamed Bouazizi in the central Tunisian town of Sidi Bouzid after his cart was confiscated by the police. From Sidi Bouzid the protests quickly spread to other cities, including the capital Tunis. Protests not only grew in size but demands increasingly expanded from calls for economic and political reforms and an end to corruption to the departure of Ben Ali. ${ }^{35}$ In January 2011 the armed forces were called out to confront the rapidly swelling demonstrations. However, when the army was deployed in different parts of Tunis, the soldiers, according to media reports, immediately fraternised with the demonstrators, apparently identifying with many of the demands voiced by 
the activists. This was in sharp contrast to the police, who by that time had already shot dead a significant number of protesters. ${ }^{36}$ Moreover, the army chief of staff, General Rachid Ammar, reportedly forbade his men from firing on the demonstrators, and issued a warning to the police that the army would retaliate if they continued shooting at the protesters. ${ }^{37}$ In the streets of Tunis, many demonstrators are said to have sought shelter from police gunshots behind the military's tanks and armoured vehicles. ${ }^{38}$ Ben Ali, dissatisfied with the behaviour of the army, reportedly tried to sack General Ammar for insubordination. ${ }^{39}$

The Tunisian army and its leadership have been credited not only with refraining from using force against demonstrators, but also with ultimately pushing Ben Ali to leave the country. While the exact role played by the army and its leaders in the final days of the Ben Ali regime has yet to be fully clarified, according to many accounts the military, and General Ammar in particular, played a decisive role. According to sources close to the former Tunisian president, including his former defence minister, there was a growing rift between the armed forces and the regime in the final days of Ben Ali, not least because the army was made subject to orders of Ben Ali's Presidential Guard in suppressing the demonstrators. This was very much resented by the military leadership. ${ }^{40}$ In the end, according to several accounts, it was General Ammar himself who, on 14 January, pressed Ben Ali to leave the country, personally telling him that he was 'finished'. ${ }^{41}$

After the president's departure, the Tunisian armed forces continued fighting remnants of the former regime which refused to surrender. In the days after Ben Ali left the country and fled to Saudi Arabia, the army was engaged in fierce battles against gunmen and armed militias loyal to the former president, as well as the Presidential Guard, which continued to hold its positions in the presidential palace. ${ }^{42}$

While the Tunisian military thus played a crucial part in the overthrow of Ben Ali, there has been at least some concern in Tunisia that the armed forces would come to play a stronger political role given the vacuum created by the end of the former regime, and the fact that the military - and General Ammar in particular - have emerged as the great heroes of the Tunisian revolution. ${ }^{43}$ At least some indications of the Tunisian army's enhanced political influence might be seen in the growing number of provincial governors with a military background who have taken 
office in the post-Ben Ali period, or, according to some sources, the strengthening of the army's grip on the Interior Ministry. ${ }^{44} \mathrm{~A}$ former interior minister of Tunisia's first transition government after Ben Ali's downfall even claimed that a military coup was being prepared by General Ammar in the event that Islamists won the next elections, although these allegations

have subsequently been denied by the transition government. ${ }^{45}$ General Ammar himself has also publicly asserted that the armed forces' role would remain strictly within the framework of the Tunisian constitution and that they would continue to act as the 'guarantor of the revolution' - although such a public appearance of the army leadership has in itself been rather unusual in Tunisia. ${ }^{46}$

Overall, Tunisia displays a high level of institutionalisation of the armed forces and a strong connection between the military and society at large due to broad-based conscription. This has resulted in a high degree of openness of the armed forces to, and even support for, the pro-reform movements. Having traditionally had an identity and legitimacy distinct from the country's regime, and being rather well-anchored in Tunisian society, the armed forces have from the outset sided with the protesters against the regime, and even seem to have been instrumental in ultimately pushing Ben Ali from power.

\section{Egypt}

Even though the popular uprising in Egypt ultimately also led to the downfall of the country's long-standing president, Hosni Mubarak, the Egyptian armed forces showed a somewhat different response to the antiregime movement compared to Tunisia. Overall, they were more hesitant to support the uprising against the country's regime. As argued below, the Egyptian military's more ambivalent attitude towards the pro-reform movement can be accounted for by its somewhat lower degree of institutionalisation and stronger relationship to the country's regime compared to the Tunisian armed forces.

The Egyptian military, not unlike its Tunisian counterpart, can be described - again by regional standards - as a professional and largely meritocratic force. It has thus been characterised by important elements of institutionalisation even though cronyism and favouritism at its highest levels seem to have been quite widespread in recent years - something 


\section{Egypt: Key facts}

Population:

$81.7 \mathrm{~m}$

Size of armed forces:

468,500

Military expenditure:

US\$3.9 bn

As percentage of GDP

$2.1 \%$

Conscription:

Yes

Beginning of protests:

25 Jan 2011

Toppling of leader:

Yes

(13 Feb 2011)

Estimated death toll:

which has been resented within the military itself. ${ }^{47}$ The armed forces are also a highly respected institution in Egypt; indeed, according to opinion polls they are the most respected institution in the country, perceived as the only one which is truly committed to upholding the national interest. ${ }^{48}$ However, in comparison to the Tunisian armed forces, the Egyptian military has, ever since the overthrow of the monarchy in 1952 by the 'Free Officers', played a much stronger political role, and has maintained a much closer relationship to the country's regime. While in Kamrava's terminology ${ }^{49}$ both Tunisia and Egypt are classified as 'autocratic officer-politician' regimes, the description is in fact much more for suitable for Egypt than for Tunisia.

The most salient connection between the Egyptian armed forces and the country's political regime has been its virtual monopoly over the allpowerful presidency: all Egyptian presidents since the overthrow of the monarchy have come from its ranks, and have de facto been selected through the officer corps. ${ }^{53}$ However, while the Egyptian military has traditionally played the role of 'kingmaker', there have been trends towards reducing the army's political role. In particular, in the aftermath of Egypt's defeat in the 1967 war, efforts were made by both Anwar Sadat and his successor, Hosni Mubarak, to limit the political influence of the army and refocus it more strongly on its purely military tasks, as its dismal performance during the war was commonly blamed on incompetence and cronyism within the armed forces. This has involved a reduction of the military presence in the Egyptian government, as well as within the state apparatus more generally, ${ }^{54}$ plus efforts to strengthen the armed forces' professionalism and combat effectiveness. ${ }^{55}$

In more recent times, the issue of presidential succession in particular led the military's political power to be put into question by the 
country's leader, and there was at least some tension between the armed forces and the Mubarak regime. While Mubarak never revealed any plans for his succession, and only appointed a vice-president in the final days of his reign, the most widely held assumption was that he was grooming his son Gamal, who has no military background, to succeed him. Needless to say, such a shift towards a 'hereditary' transfer of power would have fundamentally undermined the military's traditional hold on the presidency. From what is known, the idea of such a hereditary succession was very much resented within the Egyptian military (as it was within Egyptian society at large), including at its highest levels. ${ }^{56}$

Despite the curbing of the Egyptian military's political influence, other elements of patrimonialism have nevertheless been present, and even strengthened in recent years, in particular the Egyptian armed forces' very important economic role. This too is a characteristic which differs markedly from the Tunisian case. Beginning with arms production (which dates back to the nineteenth century), the Egyptian army has over the last decades become involved in a broad array of other economic activities, ranging from electronics to consumer goods, infrastructure development and tourism. No official data exist on the size of the military's business empire, but estimates put it at 10-40 per cent of GDP, most likely making the Egyptian armed forces the pre-eminent economic actor in the country. ${ }^{57}$ In addition to these internally generated revenues, the military has long been one of the main recipients of US military aid, receiving an average of US\$1.3 billion per year.

While the official justification for the Egyptian army's large business undertakings has been that they relieve the burden on the state budget and are thus in the general public interest, they have also given the armed forces financial resources for which it is not accountable to any other authority and which are entirely removed from public scrutiny. ${ }^{58}$ For individual military officers, these vast army businesses (and massive foreign assistance) have provided not only lucrative sources of income but also opportunities for corruption. As highlighted by one commentator: 'The huge amount of funds in circulation, with inadequate accounting supervision, virtually guarantees "leakage" into private pockets. ${ }^{59}$ Thanks to their close relationship with the regime, the Egyptian armed forces have thus far been able to keep their businesses off limits from privatisation efforts which the Egyptian economy has been undergoing since the 1980s, 
and which would have drastically curtailed the army's economic muscle. ${ }^{60}$ Analysts have seen the expansion of the Egyptian army's commercial activities as a kind of trade-off for accepting the above-mentioned limitations on its political role. ${ }^{61}$

Even though the Egyptian armed forces can be described as institutionalised to a considerable extent, and having a legitimacy relatively independent of the country's political leadership, compared to their Tunisian counterparts they have nevertheless been characterised by a higher level of patrimonialism and a stronger relationship to the regime in power. As a result, the Egyptian armed forces have been somewhat less open to the protest movements which - following the Tunisian revolution gained momentum in Egypt in January 2011. As in Tunisia, protests in Egypt evolved from demands for political and economic reforms to calls for an end to the Mubarak regime. Not unlike the Tunisian army, when in late January 2011 the Egyptian armed forces were deployed in different parts of the country to confront the massive demonstrations, they declared that the demands of the protesters were 'legitimate' and pledged to 'not use force against the Egyptian people'. ${ }^{62}$ Although initially there was some uncertainty as to the military's approach to the protests, and at least a few army vehicles were set on fire by activists, the soldiers were generally welcomed by the demonstrators. ${ }^{63}$ As in Tunisia, there was fraternisation between soldiers and protesters, with some military officers even joining the demonstrations on Cairo's Tahrir Square, which became the centre of the anti-regime movement. ${ }^{64}$ The fact that the Egyptian army is a conscript force drawn from all segments of society also seems to have contributed to its identification with the demands of the protesters.

Nevertheless, compared to the Tunisian military, the Egyptian armed forces were overall less firmly behind the protesters and showed more support for the regime, of which they ultimately had been a key pillar. The International Crisis Group summarised the situation as follows: 'Throughout the protests, the army played a consistently ambiguous role, purportedly standing with the people while at the same time being an integral part of the regime they were confronting. It found itself almost literally on both sides of the barricades. ${ }^{65}$ The army's more limited openness to, or support for, pro-reform movements was evidenced, for example, when after the first week of protests, armed Mubarak supporters riding on camels and horses charged into Tahrir Square and attacked the pro-democracy 
protesters there. ${ }^{66}$ Even though the pro-Mubarak thugs killed several demonstrators, the army units present on the square did not intervene, instead calling upon the protesters to leave the square and go home. ${ }^{67}$ This contrasted significantly with the behaviour of the Tunisian military, which actively defended anti-regime demonstrators against security forces trying to suppress the protests.

Moreover, although throughout the demonstrations the Egyptian armed forces acknowledged the legitimacy of the protesters' demands, the position of the military seemed to swing more strongly in Mubarak's favour when, in a series of televised speeches from early February onwards, the president offered some concessions to the demonstrators, including a pledge not to stand in the next presidential elections and a transfer of some of his powers to the recently appointed vice-president. While the protesters were not satisfied with these concessions, and the demonstrations continued to grow in size, the army repeatedly called upon the protesters to go home and resume normal life. ${ }^{68}$

However, on 10 February the military issued 'Communiqué No. 1', stating that the Supreme Council of the Armed Forces was in 'open-ended session to see what measures and procedures can be taken to protect the homeland and the achievements and the ambitions of the great people of Egypt ${ }^{\prime}{ }^{69}$ The issuing of such a communiqué, which mentioned neither the president nor the vice-president, is in the Arab world usually the first sign of a military coup. ${ }^{70}$ Subsequent military communiqués reflected the army's ambiguous attitude towards the protests. On the one hand, the military continued to emphasise that the demands of the people were legitimate and that 'there will be no security action taken against the honorable people who rejected corruption and called for reform'. On the other hand, the army also stressed the need to resume regular work in state institutions and to restore normal public life'. ${ }^{71}$

Finally, the Egyptian military's more limited openness to pro-reform movements was manifest in its heavy-handedness in dealing with the demonstrators and its mistreatment of activists during the protests. Even though the Egyptian armed forces have not been accused of committing the same kind of abuses as the police, who reportedly shot dead a significant number of protesters, arbitrary arrests and even torture of demonstrators by the military seem to have been quite widespread during the uprisings. ${ }^{72}$ 
While the Egyptian armed forces thus showed a more ambivalent attitude towards the protesters compared to the Tunisian military, and were more reluctant to distance themselves clearly from Mubarak, it seems that, as in Tunisia, it was the military leadership which in the end convinced the president to resign. It is still not fully clear what ultimately made Mubarak leave office, but according to many accounts there was a growing rift between the army and the president in the final days before his resignation, and top military commanders are said to have urged him to step down. ${ }^{73}$ On 11 February, only one day after Mubarak had publicly vowed to serve out his current term of office, he resigned and handed power to the Supreme Council of the Armed Forces. The army, for its part, declared in a further communique that it would take over the political leadership of the country only temporarily, and work towards transferring its powers to an 'elected civilian authority' within a 'free democratic state $^{\prime 74}$

The Egyptian armed forces' ambiguous attitude towards pro-reform movements has continued into the post-Mubarak period, during which the Supreme Council of the Armed Forces has effectively ruled the country. At times the army has cracked down quite forcefully on demonstrators who have continued to take to the streets to express their dissatisfaction with the pace and extent of reforms. In early April 2011 military heavyhandedness even resulted in the death of two protesters on Tahrir Square. ${ }^{75}$ Moreover, while criticising and even ridiculing the former president and his regime have become acceptable, expressing criticism of the military has remained off limits. ${ }^{76}$ According to human rights organisations, restrictions on freedom of expression have in fact intensified since the Supreme Council of the Armed Forces took over power, at least as far as criticism of the armed forces is concerned, and a growing number of civilians have been tried by military tribunals for 'insulting the military'. ${ }^{77}$

On the other hand, the military leadership has shown a considerable degree of responsiveness to the demands of the demonstrators. The Supreme Council of the Armed Forces' most significant step against the former president and his entourage has been the detention and putting on trial of Mubarak and his sons for corruption, as well as on charges of complicity in murder by ordering the use of force during the demonstrations. While this has been one of the main demands of the 
protesters, the prosecution of the country's former president and supreme commander has arguably marked an unprecedented development in Egypt.

Even though demonstrations have continued after the fall of Mubarak, and there have even been calls for the resignation of the head of the Supreme Council of the Armed Forces, Field Marshal Mohammed Tantawi, the Egyptian armed forces, like their Tunisian counterparts, have enjoyed great popularity as a result of their role in ousting the former president. According to an opinion poll conducted by the Pew Research Center after the fall of Mubarak, 88 per cent of respondents thought the military was having a positive influence on developments in Egypt, and fully 90 per cent had a favourable view of Field Marshal Tantawi. ${ }^{78}$

Overall, the Egyptian armed forces showed a lesser degree of openness towards the pro-reform movements compared to their Tunisian counterparts. Although the Egyptian military ultimately sided with the protesters against Mubarak, and like the Tunisian army seems to have played a key role in the president's resignation, it generally showed more reluctance to support the cause of the protesters clearly and distance itself from the country's leader. ${ }^{79}$ This difference to the Tunisian case can be explained by a somewhat lower degree of institutionalisation of the Egyptian armed forces, and the fact that its identity has been more closely bound up with the Egyptian regime. While a number of elements of institutionalisation have certainly been present in the Egyptian military such as its high level of professionalism, its general functioning according to meritocratic principles and its overall commitment to the national interest there are also important patrimonial characteristics, as evidenced in particular by its traditional hold on the Egyptian presidency and its privileged status as a very important economic actor in Egypt. 


\section{FRACTURING OF THE ARMED FORCES}

Another scenario of armed forces' response to pro-reform movements can be observed in Libya and Yemen, where the military has effectively broken up when confronted with a popular uprising. In both countries the antiregime movement has practically resulted in a civil war - although thus far of lesser intensity in Yemen than in Libya - with the most elite units of the armed forces violently defending the regime and suppressing the uprising, and other elements of the military siding with the opposition. In both Libya and Yemen this can be explained as a result of a combination of a very low level of institutionalisation and a high degree of fragmentation of the armed forces, as well as a relatively strong connection between at least parts of the military establishment and the population.

\section{Libya}

When it comes to the armed forces' level of institutionalisation, Libya represents an extreme case. If Tunisia, with its highly institutionalised and largely apolitical army, represents one end of the spectrum of Arab countries, Libya is arguably located at the very other end of the spectrum: the lack of institutionalisation and the level of patrimonialism and politicisation of the security apparatus have arguably nowhere been higher than in Libya. Following long-standing leader Muammar Qaddafi's vision of a 'stateless society', the Libyan political system as a whole has been largely devoid of functioning state institutions, dominated instead by patrimonial 


\begin{tabular}{ll|}
\hline Libya: Key facts & \\
Population: & $6.1 \mathrm{~m}$ \\
Size of armed forces: & 76,000 \\
Military expenditure: & US\$1.1 bn \\
As percentage of GDP: & $1.2 \%$ \\
Conscription: & Yes \\
Beginning of protests: & 15 Feb 2011 \\
Toppling of leader: & Yes \\
& (Tripoli captured on \\
& $\begin{array}{l}22 \text { Aug 2011 - } \\
\text { Qaddafi killed on }\end{array}$ \\
& 20 Oct 2011) \\
Estimated death toll: & 30,000 \\
& \\
\hline
\end{tabular}

rule centred on the Libyan leader and his family. In the same way, the country's most important security forces have been based primarily on tribal and family ties to Qaddafi himself. ${ }^{80}$

While in Kamarava's terminology ${ }^{81}$ Libya under Qaddafi can be categorised as a 'dual military' regime, it is more adequately described as a 'multiple military' regime. In addition to the regular army, whose main task has been to defend the country against external threats, Libya also had a plethora of other security agencies principally aimed at protecting the Qaddafi regime and its ideology. These included the so-called Revolutionary Committees, the Revolutionary Guards and the People's Guards, whose main mission was to uphold Qaddafi's 'revolutionary' system and ideas, as outlined in his Green Book. All these bodies were led by Qaddafi's relatives or members of his own or particularly loyal tribes. ${ }^{82}$

Even within the regular army, the most elite units were commanded by close relatives of the Libyan leader, and were concerned primarily with securing the Qaddafi regime. The most notorious among these was the socalled 32nd or Khamis Brigade, which was led by Qaddafi's youngest son, Khamis. The Khamis Brigade reportedly counted some 10,000 men and was equipped with a variety of heavy weaponry, including battle tanks, helicopters and rocket launchers. ${ }^{83}$ It was commonly considered Libya's best trained and equipped force, and the main coercive instrument of the regime. ${ }^{84}$ Qaddafi's other sons were also said to command special army units. ${ }^{85}$

Apart from this multitude of tribally or family-based and highly ideological security forces, another noteworthy characteristic of the Libyan security apparatus was the so-called People's Militia. Rejecting the idea of a 
classic army which would defend the Libyan people, Qaddafi believed in the Bedouin practice of collective self-defence. ${ }^{86}$ He thus created the People's Militia as an auxiliary force to the regular army. While the People's Militia ultimately was to comprise all age groups of Libyan society, its manpower was estimated at some 45,000 members and its military effectiveness was probably largely symbolic. ${ }^{87}$ Finally, Qaddafi traditionally also relied heavily on foreign mercenaries. In the 1970s, for example, he set up the so-called Islamic Legion, composed mainly of migrants from poorer Sahelian countries, to support Libya's military activities in Africa. ${ }^{88}$ It is commonly agreed that the creation of such a fragmented military structure and the sidelining of the regular army, which came at the expense of military effectiveness, was a deliberate policy of the Libyan leader in his effort to prevent the emergence of any alternative political power base capable of challenging his regime. ${ }^{89}$

The Libyan military under Qaddafi can thus be described as highly patrimonial and fragmented, but at least in part as organically linked to Libyan society. Its most sophisticated and elite units were based entirely on tribal and family connections to the Libyan leader, and had no raison d'être outside the Qaddafi regime. The concept of the People's Militia, on the other hand, suggests a relatively close relationship between at least parts of the country's security forces and Libyan society, although the opposite can be said of the use of foreign mercenaries.

These features shaped the Libyan armed forces' response to the antiregime uprisings which erupted in different parts of the country in early 2011. When the protests began in February 2011, parts of the Libyan army defected relatively quickly to the opposition. Qaddafi reportedly even put Libya's army chief, Abu Bakr Yunis Jabir, under house arrest, most likely out of fear of a military coup. ${ }^{90}$ In the eastern city of Benghazi, which became the stronghold of the rebels, defecting army units are said to have overpowered pro-Qaddafi forces and driven them out of the city. ${ }^{91}$ The highest-profile defection within the Libyan armed forces was General Abdul Fatah Younis, Qaddafi's interior minister, whose 'Thunderbolt unit' was reportedly instrumental in ousting Qaddafi's forces from Benghazi. ${ }^{92}$ However, while the uprisings in Benghazi could hardly have been successful without the defection of parts of the army, it seems that many of the defecting soldiers subsequently melted back into Libyan society. According 
to reports from the front lines, rebel forces were made up to a large extent of fighters with little or no military training or experience. ${ }^{93}$

On the other hand, the loyalty of the elite units most closely linked to Qaddafi's regime was unwavering until the very end, and they responded without restraint to the popular uprisings. The Khamis Brigade in particular was at the forefront in fighting the opposition, although the Revolutionary Committees reportedly also played a role in suppressing the protests. ${ }^{94}$ After the rebels initially succeeded in moving westwards from Benghazi, bringing a number of towns under their control, they were subsequently thrown back by the Khamis Brigade. ${ }^{95}$ Indeed, it is often argued that without the Western airstrikes which began on 19 March 2011, Qaddafi's much better trained and equipped troops may well have succeeded in recapturing the city of Benghazi.

It is noteworthy that pro-Qaddafi forces did not refrain from using their heaviest weapons such as aircraft, tanks and heavy artillery against the anti-regime movement, even though within the Libyan air force there were defections. ${ }^{96}$ The bloodiest battle of the Libyan uprising took place over the town of Misrata, which was besieged and shelled with heavy artillery for several months by Qaddafi's forces. The United Nations has estimated that some 300 people were killed in Misrata alone, the majority of whom were civilians. Moreover, according to the UN Security Council, some of the killings 'may count as crimes against humanity'.

Following his tradition of relying on foreign fighters, Qaddafi also unleashed mercenaries from sub-Saharan African countries such as Mali, Niger and Chad against the anti-regime movement, although estimates of their numbers have varied widely. ${ }^{98}$ Mercenaries fighting for Qaddafi were reportedly paid $€ 500$ per day and $€ 9,000$ for every Libyan killed. ${ }^{99}$ According to one captured colonel of Qaddafi's forces, one of the main tasks of these mercenaries was to prevent defections within the regular army and ensure that Qaddafi's troops continued fighting the uprising. ${ }^{100}$ There have also been reports that foreign mercenaries, in particular, were ordered by the Qaddafi leadership to use rape in fighting the rebellion. ${ }^{101}$

Towards mid-2011, after some six months of fierce fighting between pro- and anti-Qaddafi forces, the military balance gradually began to shift towards the latter. In August 2011 the rebels succeeded in bringing the Libyan capital Tripoli, including Qaddafi's main military headquarters, the Bab al-Aziziya compound, under their control. With the taking of Tripoli by 
opposition fighters, Qaddafi's reign de facto came to an end, even though pro-Qaddafi forces continued to mount fierce resistance, notably in Qaddafi's home town of Sirte, where the Libyan leader and some of his sons had fled after Tripoli had fallen. At the end of October, Qaddafi himself was captured and killed in Sirte by rebel fighters, after which the new (interim) Libyan government - the so-called National Transitional Council - gained control over practically the entire country. The eventual prevailing of the opposition over Qaddafi's forces was arguably the result of a number of factors, such as improved military organisation and experience on the part of the rebels, the launching of Western airstrikes and the imposition of the UN no-fly zone, which incapacitated Qaddafi's air force and much of his other heavy weaponry, as well as direct military support to the rebels by some Western countries in the form of arms deliveries and military advisers on the ground.

Overall, it can be argued that the highly patrimonial nature of the Libyan military, at least its most elite units, and the use of foreign fighters with no connection to Libyan society resulted in a very violent response to pro-reform movements by Qaddafi's forces until the regime's eventual collapse. Being intimately tied to Qaddafi and his family, and having no legitimacy outside the regime, the elite elements of Libya's armed forces showed no restraint in seeking to crush the popular uprising. Moreover, the use of foreign soldiers motivated primarily by financial rewards certainly contributed to the harshness of the response against the anti-regime movement.

On the other hand, the virtually total lack of institutionalisation and highly fragmented nature of Libya's armed forces, as well as the fact that at least some elements of the country's military were arguably well anchored in Libyan society, led to a fracturing of the armed forces, with defections and support for anti-regime uprisings on a significant scale. The end result was a six-months-long bloody civil war between pro- and anti-Qaddafi forces. Thus even though the Libyan uprising, like the Tunisian and Egyptian revolutions, was ultimately successful and led to the toppling of the country's leader, this has come at a considerably higher cost in human lives: whereas the death toll of the Tunisian and Egyptian revolutions numbered in the hundreds, in Libya estimates have put the number of casualties as at least 30,000 , with another 50,000 wounded. ${ }^{102}$ 
Yemen

\begin{tabular}{|c|c|}
\hline \multicolumn{2}{|l|}{ Yemen: Key facts } \\
\hline Population: & $23 \mathrm{~m}$ \\
\hline Size of armed forces: & 66,700 \\
\hline Military expenditure: & US\$1.2 bn \\
\hline As percentage of GDP: & $3.9 \%$ \\
\hline Conscription: & Yes \\
\hline Beginning of protests: & 27 Feb 2011 \\
\hline Toppling of leader: & $\begin{array}{l}\text { No, but severely } \\
\text { injured in attack } \\
\text { and (temporarily) } \\
\text { fled abroad }\end{array}$ \\
\hline Estimated death toll: & 225 \\
\hline
\end{tabular}

In Yemen the popular uprising has resulted in a situation somewhat similar to that observed in Libya, i.e. a fracturing of the armed forces and practically a civil war, even if the war in Yemen has thus far remained a relatively lowintensity conflict. In Kamrava's terminology ${ }^{103}$ Yemen is classified as an 'autocratic officer-politician' regime, which is correct in the sense that Yemen's long-standing president, Ali Abdullah Saleh, is indeed a former military officer, and that the armed forces have been the main pillar of his regime. However, this characterisation does not sufficiently highlight the importance of tribal (and family) ties which have been a core element of Yemen's security establishment, as well as Yemeni society more generally. Just as Yemen is a largely tribally based society, so have the armed forces been dominated by tribal and family allegiances. The officer corps of the Yemeni military, for example, is made up mainly of tribal elites, whereas the rank and file hail from the non-tribal peasantry. ${ }^{104}$ Key positions within the Yemeni armed forces are all held by members of President Saleh's Sanhan tribe, and the most sensitive and powerful posts are occupied by close family members. The Republican Guard, Yemen's most elite military force, is commanded by Saleh's son Ahmed, while his nephews control the security forces charged with protecting the capital and the regime. Similarly, the Yemeni air force is headed by a half-brother of the president. ${ }^{105}$

Tribalism is not only an important factor within Yemen's armed forces, but also outside the country's formal security structures. In addition to the regular army, Yemen's tribes have their own militias, estimated to 
number some 20,000 men. ${ }^{106}$ Moreover, Yemen is one of the best-armed countries in the world, as all Yemeni tribesmen (above the age of 15) traditionally carry arms, usually an assault rifle. It is estimated that Yemen's tribes hold around four times as many firearms as the country's state security forces. ${ }^{107}$

While tribalism is a key element of Yemeni society and the country's security establishment, some analysts have argued that in recent years the tribal factor has declined in significance and it would be misleading to assume that Yemen's tribes are coherent blocs. As tribal leaders have become part of the country's regime and its extensive patronage system, tribal identities and loyalties are generally said to have weakened. ${ }^{108}$ This was shown in the 1994 civil war between north and south Yemen, where the tribal factor was largely absent. ${ }^{109}$ Instead of tribes, Yemeni politics increasingly seems to be dominated by competition between individual 'strongmen', sometimes from within the same tribe, vying over political power and influence. ${ }^{110}$

Apart from the above-mentioned tribal factors, another manifestation of patrimonialism within Yemen's military has been widespread cronyism and corruption. Yemen is regarded as one of the most corrupt countries in the world, and within the security forces corruption is said to have been particularly rampant. ${ }^{111}$ The International Crisis Group described the situation as follows: 'Powerful commanders from the president's family manage divisions more like private fiefdoms than components of a national institution. ${ }^{112}$ Patronage and corruption within the Yemeni military have reportedly occurred through a variety of mechanisms. The 'simplest' form is the massive misappropriation of funds from Yemen's vast military budget, which lacks any form of accountability and transparency. ${ }^{113}$ Another practice by which military commanders reportedly have been able to enrich themselves is the use of 'fictitious soldiers'. Commanding officers are allocated financial resources based on the number of soldiers in their units, to cover their salaries, weapons, food, etc. It is said that there has been widespread use of 'ghost' soldiers as a means for senior officers to pocket funds for troops who exist on paper only. It is estimated that around one-third of Yemen's military personnel might be purely fictitious. ${ }^{114}$

The Yemeni military can thus be described as highly patrimonial, and practically devoid of any form of institutionalisation. The armed forces are 
virtually a 'family business' of the Saleh clan, and a source of massive and unaccountable income for military commanders. Similar to Libya (and somewhat different from the cases of Bahrain and Syria discussed below) the lack of institutionalisation of the Yemeni military is such that one can hardly speak of a coherent national institution. The armed forces rather seem like a patchwork of individual 'fiefdoms' controlled and exploited by their respective commanders.

Turning to the other factor examined here - the linkage between the military and society at large, and in particular the issue of conscription - it can be noted that in 2001 Yemen abolished its two-year compulsory military service, relying instead entirely on volunteers. In 2007, however, conscription was reintroduced in an effort to combat unemployment. The expectation at the time was that some 70,000 new recruits would join the army. ${ }^{115}$ Although difficult to assess without more detailed information, it can thus be assumed that the Yemeni armed forces are at least to some extent anchored in the population at large.

As in Libya, the highly patrimonial nature of Yemen's armed forces has resulted in strong opposition to pro-reform movements, at least in those units most closely linked to the Saleh regime. However, and again comparable to Libya, there has also been a splintering of the military when facing the popular uprising, with at least some elements of the armed forces siding with the anti-regime movement.

The popular upheavals in Yemen, similarly to those of other Middle Eastern countries, began as a grassroots movement led by students and civil society activists calling for political and economic reforms as well as an end of the Saleh regime. However, while students were the initial driving force behind the uprising, opposition parties as well as tribal and religious leaders subsequently joined the protests. ${ }^{116}$ The most significant support for the pro-reform movement has come from the Hashid tribal federation, one of the most important tribal federations in the country's north and to which Saleh's own tribe belongs. In late February 2011 Hashid tribal leader Sheikh Hussein bin Abdullah Al-Ahmar resigned from his official functions within the country's ruling party, the General People's Congress, and declared his support for the anti-regime uprising. ${ }^{117}$

The response of the Yemeni army and the country's other security forces to the popular uprising has, from the outset, been a very harsh one. Whereas initially armed regime supporters in plain clothes seem to have 
been at the forefront in suppressing the pro-reform movement, the armed forces have also played an important role in this respect. In early March 2011 the army stormed Sanaa's university campus, where demonstrators had been camping, using live ammunition and killing at least one protester. ${ }^{118}$ When there was another massive demonstration in midMarch, soldiers opened fire on the protesters, reportedly killing 46 and wounding hundreds. ${ }^{119}$

However, just as the uprisings have led to a split in the political leadership of Yemen, so have the armed forces fractured when confronted with the anti-regime movement. Shortly after the government's violent crackdown on the demonstrations, several senior commanders of the Yemeni army defected to the opposition. The highest-level defector has been General Ali Mohsen al-Ahmar, head of the Yemeni army in the northwest, who according to some sources is a half-brother of President Saleh. ${ }^{120}$ In March 2011 General Mohsen announced that he would join the revolution, and deployed troops and tanks of his First Armoured Division in Sanaa to protect the protesters against government forces. ${ }^{121}$

The Yemeni defence minister declared that, despite these defections, the army was still behind the president and would defend him against any 'coup against democracy'. ${ }^{122}$ Only minutes after General Mohsen rallied behind the protesters, the Republican Guard deployed tanks at strategic locations in the capital, including the president's residence, the Ministry of Defence and the central bank. ${ }^{123}$ Fighting between pro- and antigovernment forces escalated sharply after Saleh repeatedly rejected peace deals put forward by the Gulf Cooperation Council (GCC), under which he would leave office. Since May 2011 there have regularly been violent clashes, between forces loyal to President Saleh on the one hand and General Mohsen's troops and tribal militias on the other, over control of government buildings in Sanaa and elsewhere. ${ }^{124}$ In early June 2011 President Saleh himself was severely wounded in a rocket attack on his presidential palace and flew to Saudi Arabia for treatment. ${ }^{125}$ However, Yemeni armed forces still loyal to the president have vowed to continue defending Saleh's rule. According to Yemeni media reports, the president's son and commander of the Republican Guard rather than the official vicepresident has even taken de facto power in Yemen. ${ }^{126}$ According to Human Rights Watch, a total of 225 people have thus far been killed during the uprising in Yemen and at least 1,000 wounded. ${ }^{127}$ 
As of late 2011 the outcome of the popular uprising in Yemen still seemed uncertain, with the capital Sanaa roughly divided between forces loyal to President Saleh and opposition fighters. For the purposes of our analysis, however, the Yemeni case is overall quite similar to Libya, as a result of similar forms of civil-military relations in the two countries. In both countries a highly patrimonial and largely deinstitutionalised military has fractured when confronted with an anti-regime uprising, resulting in a civilwar-type scenario. While those units most closely linked to the respective regimes have violently cracked down on the pro-reform movements, other elements of the armed forces have sided with the opposition. In both cases the splintering of the army seems to have been furthered by a combination of a high degree of patrimonialism on the one hand, and a relatively close linkage between at least parts of the military establishment and society at large on the other. 


\section{CRACKDOWN ON PRO-REFORM MOVEMENTS}

A third type of response to pro-reform movements was shown by the armed forces of Bahrain and Syria. In these two countries the military has violently suppressed the popular uprisings while (largely) maintaining its unity. In both Syria and Yemen the armed forces' firm opposition to the pro-reform movements can be seen as a consequence of the patrimonial nature of the military and - in contrast to Libya or Yemen - the (relatively) weak relationship between the military establishment and the population, mainly as a result of the sectarian bias characterising the armed forces of the two countries.

\section{Bahrain}

In Kamrava's typology ${ }^{128}$ Bahrain is adequately classified as a 'tribally dependent monarchy'. Indeed, Bahrain's security establishment, like that of other Gulf monarchies, is not only based on tribal connections but is entirely dominated by the ruling Khalifa family: all of the most important positions within Bahrain's security forces, such as the minister of defence, chief of staff, assistant chief of staff, chief of naval staff and commander of the air force, are firmly in the hands of relatives of the monarch. ${ }^{129}$

Apart from these tribal and family ties, two other distinctive features of Bahrain's security apparatus stand out: the exclusion of the Shia majority population from the country's security establishment, and the heavy reliance on foreign fighters. Even though some two-thirds of Bahrain's 


\begin{tabular}{|ll|}
\hline Bahrain: Key facts & \\
Population: & 718,000 \\
Size of armed forces: & 8,200 \\
Military expenditure: & US\$731 m \\
As percentage of GDP: & $3.7 \%$ \\
Conscription: & No \\
Beginning of protests: & 14 Feb 2011 \\
Toppling of leader: & No \\
Estimated death toll: & 36 \\
\hline
\end{tabular}

paramilitary Special Security Forces. ${ }^{130}$ population are Shia, their presence in the country's security forces has been minimal. Shias are not allowed to serve in Bahrain's armed forces, and their share in the country's other security agencies has been very limited. According to Bahrain's Centre for Human Rights, Shias make up less than 5 per cent of the country's main internal security institution, the National Security Agency, and are not at all represented in the

While Bahrain's Shiite population has been largely excluded from the country's military and security structures, the proportion of foreigners in these forces has been extremely high. Again according to Bahrain's Centre for Human Rights, three-quarters of members of the National Security Agency are (Sunni) foreigners, and the share of non-Bahrainis in the Special Security Forces is said to be as high as 90 per cent. ${ }^{131}$ Foreign security officers have hailed mainly from Syria, Jordan and Yemen, and have reportedly been recruited and granted Bahraini citizenship in an effort to counterbalance Shiite demographic predominance. Nevertheless, Bahrainis continue to view them as foreign mercenaries who often do not speak the local dialect. ${ }^{132}$

Bahrain's military and security forces can thus be described as both patrimonial and largely detached from the local population. The country's armed forces are entirely dominated by the ruling family, and there is no organic link between the security establishment and Bahraini society as a result of not only the exclusion of the Shia majority population but also the presence of a very large number of foreigners within the country's security agencies. The main difference to the cases of Libya and Yemen is that, despite their patrimonial nature, the Bahraini armed forces seem to be a relatively cohesive institution, in contrast to Libya's and Yemen's highly fragmented military forces. Moreover, while the Libyan and Yemeni 
militaries are at least to some extent anchored in society at large, the same cannot be said of Bahrain's armed forces.

These features have been reflected in the response of Bahrain's security forces to the pro-reform movements which erupted in the wake of Mubarak's resignation in February 2011. Demonstrators in Bahrain have come mostly from the Shiite population. They have called for democratic reforms, respect for human rights and an end to the discrimination suffered by Shias in all sectors of public life. ${ }^{133}$ Moreover, as in other countries of the region, the demands of the protesters have expanded over time to calls for an end to the Khalifa monarchy. ${ }^{134}$ As would be predicted in the case of a security apparatus characterised by a high level of patrimonialism and a weak relationship to society at large, Bahrain's security forces have shown fierce opposition to the pro-reform movements and forcefully suppressed the popular uprising. The government crackdown on the demonstrations began on 17 February, when the Bahraini leadership deployed military and police forces in the capital Manama, declaring that the army had taken control over 'key parts' of the city. ${ }^{135}$ Security forces then surrounded the activists on 'Pearl Roundabout', which had become the centre of the protests. Many of the demonstrators were reportedly still asleep when the security forces started firing rubber bullets and tear gas at them, killing at least five protesters and injuring more than $200 .{ }^{136}$

Protests subsequently escalated, as did the regime's response to them. In the following days pro-democracy activists blocked the entrance of parliament as well as Manama's main financial district, while the demonstrations on Pearl Roundabout continued to grow in size. In midMarch 2011 Bahrain's leadership declared a state of emergency and requested support from the GCC within the framework of its Joint Defence Agreement. ${ }^{137}$ In response, Saudi Arabia despatched some 1,000 soldiers and the United Arab Emirates (UAE) 500 police officers to suppress the protests. Reinforced by these additional troops, Bahraini security forces succeeded in clearing the square, leaving another five dead and hundreds more injured. ${ }^{138}$ When in late March 2011 activists aimed to organise a 'day of rage' in the form of renewed massive demonstrations, these were quickly crushed by security forces, indicating that the latter had gained the upper hand against the popular uprising. ${ }^{139}$

Bahraini forces even attacked and took over the hospital in which injured protesters were being treated, beating and arresting several 
medical personnel working there. ${ }^{140}$ In September 201120 medics from the hospital who had treated demonstrators during the uprising were sentenced to between five and 15 years in prison by a military court in Bahrain for alleged crimes against the state. ${ }^{141}$

In sum, the popular uprising in Bahrain has been fiercely suppressed by the country's army and other security forces. This harsh response to the pro-reform movements can, again, be explained by the particular nature of civil-military relations and the military apparatus in Bahrain. The two key factors identified here - patrimonialism and a weak relationship between the security establishment and society at large - have resulted in firm opposition and a harsh crackdown of the country's security forces on the anti-regime movement.

The resort to Saudi and Emirati troops by the Bahrain leadership to crush the popular uprising has underscored and further contributed to the distance between the Bahraini security establishment and the local population, as both the regime and the opposition have considered themselves as being engaged in a struggle with foreign forces. The security assistance provided by Saudi Arabia and the UAE to quell the unrest in Bahrain has been made available under a clause of the aforementioned GCC Joint Defence Agreement which stipulates mutual military support in the event of an external threat. ${ }^{142}$ At least implicitly, the uprising in Bahrain has thus been treated by the country's regime as foreign aggression rather than (purely) an internal matter. This has been mirrored by the discourse of Bahrain's pro-reform movement, which has viewed the sending of foreign troops to assist the regime as outside interference and an act of 'occupation', rather than a domestic response. ${ }^{143}$ Both the regime and the opposition have thus seen themselves as facing, at least in part, aggression by external forces rather than being involved in an internal struggle.

\section{Syria}

Syria is another Arab country which has experienced a rather broad popular uprising against the regime. However, compared to other countries of the region, pro-reform movements have been slower to gain momentum, and at least until late 2011 have remained more limited in size. A discussion of the specific nature of the Syrian uprising is beyond the scope of this paper; suffice it to note here that analysts have pointed to a number of factors 


\begin{tabular}{|ll|}
\hline Syria: Key facts & \\
Population: & $19 \mathrm{~m}$ \\
Size of armed forces: & 292,600 \\
Military expenditure: & US\$2.2 bn \\
As percentage of GDP: & $4 \%$ \\
Conscription: & Yes \\
Beginning of protests: & 26 Jan 2011/ \\
& 15 Mar 2011 \\
Toppling of leader: & No \\
Estimated death toll: & 3,000 \\
\hline
\end{tabular}

which seem to have made a massive popular movement against the regime on the scale of Tunisia or Egypt more unlikely in Syria. These include, in particular, Syria's foreign policy and strategic posture, which are said to be more in line with public opinion and the 'Arab street', President Bashar Al-Assad's personal standing and reputation as a (relative) reformer and Syria's sectarian divisions. ${ }^{144}$

When it comes to the response of the armed forces to the anti-regime movement, the Syrian case most closely resembles that of Bahrain; as in the latter case, and somewhat in contrast to Libya or Yemen, the Syrian military (as well as the country's other security forces) has forcefully cracked down on the popular uprising, without a splintering of the armed forces or defections on a significant scale. As in Bahrain, the armed forces' resistance to the pro-reform movement can be explained by a rather high degree of patrimonialism within the country's military establishment (and its security forces more generally), as well as a relative weak relationship between the armed forces - at least their higher echelons and most elite units - and Syrian society at large.

Kamrava ${ }^{145}$ classified Syria as an 'autocratic officer-politician' regime, which makes sense given the key role played by the army in Syrian politics since independence, and the fact that Syria's long-standing president, Hafez Al-Assad, was a military officer, relying on the military (in addition to the Baath party) as a main pillar of his reign. ${ }^{146}$ The most noteworthy - and bloody - incident where Hafez Al-Assad used the armed forces to ward off an internal challenge to his rule was the crushing of an Islamist uprising in the city of Hama in 1982, where between 10,000 and 40,000 people are estimated to have been killed by Syrian security forces. Moreover, even though Hafez's son and current ruler, Bashar Al-Assad, initially did not have much of a military background, training instead to become an 
ophthalmologist, once it became clear that Bashar would succeed his father, he received accelerated military training and was rapidly promoted within the military hierarchy. Prior to being elected as president, Bashar AlAssad was promoted to the position of general commander and assumed the highest rank within the Syrian military hierarchy, highlighting the importance of the Syrian army's loyalty to his rule. ${ }^{147}$

However, not unlike the case of Yemen, the notion of an 'autocratic officer-politician' regime does not sufficiently take into account tribal and sectarian factors which have played a key role within Syria's political system, including its military establishment. The coming to power of Hafez Al-Assad marked the assumption of a predominant political role by Syria's once-marginalised Alawite minority, from which the Al-Assad family hails. ${ }^{148}$ Under Assad, the Alawites came to dominate Syria's political system as a whole, using the armed forces and the country's numerous other security agencies as their main power base, in which they have been vastly overrepresented. Thus while Alawites make up only around 12 per cent of the Syrian population, they account for 70 per cent of career soldiers in the Syrian armed forces. The imbalance is even more pronounced in the officer corps, where 80-90 per cent are estimated to be Alawites. ${ }^{149}$ Moreover, the country's most elite military units are exclusively Alawite, and are commanded by close relatives of Assad. The Republican Guard, for instance, is headed by the current president's younger brother, Maher AlAssad. Even in those military units where Sunnis have been numerically predominant, efforts have been made to subject them to tight Alawite control. For example, while most of Syria's air force pilots are Sunni, they are held in check by ground support staff who control logistics and in particular the air force intelligence service, both of which are predominantly Alawite. ${ }^{150}$

Apart from these sectarian, tribal and family ties, the Syrian military establishment has also been marked by other patrimonial characteristics. There is generally said to have been widespread cronyism and favouritism within the army under Hafez Al-Assad. Even though, in the aftermath of Syria's defeat in the Six Days War against Israel, Hafez aimed to depoliticise the armed forces and strengthen their professionalism, these efforts were much more limited than in the case of Egypt. While promotion based on competence rather than loyalty became more common among junior officers, at senior levels Hafez Al-Assad continued to make appointments 
primarily based on political considerations and personal commitment to him. ${ }^{151}$ For example, he appointed several of his close associates to the prestigious position of air force commander, even though they had practically no experience as pilots. ${ }^{152}$ Moreover, a common practice of the former president was to ensure the loyalty of his generals through generous financial rewards and allowing them to 'turn their units into political and economic fiefdoms'. ${ }^{153}$ Pillaging and racketeering in Lebanon used to be one main way in which Syrian military commanders were able to enrich themselves, at least until the withdrawal of the Syrian army from the country in 2006. ${ }^{154}$

When Hafez's son Bashar came to power in 2000 he launched an anti-corruption campaign within the country's security forces, but due to the deep-rooted nature of the phenomenon, this is said to have been largely unsuccessful. ${ }^{155}$ In the initial years of his reign, Bashar also removed a number of 'old guard' figures within the country's security apparatus, according to some commentators with the aim of shifting power from the military and intelligence services to the civilian cabinet. However, these efforts too do not seem have significantly curbed the army's predominant role within Syria's political system. ${ }^{156}$ Moreover, even though Bashar promoted a few Sunnis to high-level positions in the country's security agencies, overall he has continued the practice of appointing close family members and friends to the most senior and sensitive positions within Syria's security establishment. ${ }^{157}$

The Syrian army can thus be characterised as a largely patrimonial force. It has been dominated by sectarian and family ties to the Syrian regime, with widespread emphasis on cronyism and favouritism, despite certain reform efforts by Bashar Al-Assad. Instead of being a relatively apolitical institution committed to the national interest, the army has rather been one of the main instruments through which the Alawite minority has ensured its grip on the Syrian political system.

As for the other factor taken into account here - the relationship between the army and society at large - given the military's sectarian bias, its connection with the population can be described as relatively weak, or at least not as strong as in countries such as Egypt or Tunisia. Even though the Syrian army is a conscript force in which most troops come from the Sunni majority population, there is a clear bias in favour of the Alawite minority among its professional soldiers and even more so within the officer corps. 
Moreover, as argued above, its most elite units and most senior commanders are entirely Alawite.

As would be expected from a military force characterised by patrimonialism and a relatively weak relationship to the population at large, the Syrian army has forcefully cracked down on the pro-reform movement. When anti-regime protests gained momentum in a number of Syrian towns during the latter half of March 2011, these were violently suppressed by the military (as well as the country's other security forces). A common strategy of the Syrian army in dealing with the demonstrations has been to use tanks and snipers to keep people off the streets. According to defecting soldiers interviewed by Human Rights Watch, troops sent to towns experiencing anti-regime demonstrations and unrest were usually told by their superiors that they would be fighting foreign infiltrators, religious extremists and terrorists. When the soldiers encountered unarmed protesters, they were nevertheless ordered to open fire on them. These defectors also reported that secret service agents were usually deployed alongside soldiers to ensure they followed orders, and soldiers who refused to shoot protesters were themselves executed by their superiors. ${ }^{158}$ Certainly this explains the high death toll which the military crackdown on demonstrations in cities such as Daraa, Hama and Homs has exacted. ${ }^{159}$

Even though according to some observers the Syrian regime has been showing more restraint since around mid-2011 in dealing with the protests, resulting in fewer casualties, it is also the case that heavy weaponry has been used increasingly by the Syrian army to suppress the demonstrations. ${ }^{160}$ In June 2011 the army for the first time used helicopter gunships equipped with machine guns to disperse pro-democracy protests in the town of Maarat al Numaan, killing numerous people. ${ }^{161}$ In August 2011 the regime even mobilised the navy to quell the uprising, shelling the Mediterranean port city of Latakia from warships deployed off the Syrian coast. ${ }^{162}$ The overall death toll caused thus far by Syrian security forces' suppression of the uprising has been estimated by UN officials at more than $3,000 .{ }^{163}$ Moreover, as a result of the government crackdown, at least 20,000 Syrians are thought to have fled across the border into neighbouring Turkey and Lebanon. ${ }^{164}$

While the Syrian armed forces (and the country's other security agencies) have thus violently suppressed the pro-reform movement, the main difference to the case of Bahrain is that there have, as suggested 
above, been at least some defections within the Syrian army, and according to media reports - executions of soldiers for insubordination. ${ }^{165}$ In particular since mid-2011, defections mainly of lower-level troops (who are predominantly Sunni) seem to have been on the rise, and a so-called Free Syrian Army composed of military units which have turned against the Assad regime is said to have been set up. ${ }^{166}$ Given the limitations of independent media coverage in Syria, it is of course difficult to assess the scale of this phenomenon. However, commentators close to events in Syria seem to be agreed that despite growing numbers of defections from the army, these have so far remained relatively limited, not least due to tight control by the Alawite-dominated officer corps, and unable to mount a serious challenge against the Assad regime and its security forces. ${ }^{167}$

Given the obscure nature of the Syrian regime, it is also not possible to assess to what extent President Bashar himself has been behind the Syrian security forces' ruthless suppression of the pro-reform movements. Given his self-professed image as a moderate and reformer, there are at least some reasons to suspect that Bashar would have preferred a different approach to the popular uprising, and that government oppression has been driven mainly by the security forces themselves. Some observers have even suggested that the true 'first in command' in Syria might no longer be Bashar himself, but rather his younger brother Maher, who as mentioned previously controls the army's most elite military units, including the Republican Guard. ${ }^{168}$

Regardless of President Bashar's own position, however, it is clear that the Syrian armed forces have generally shown fierce opposition to the pro-reform movements. From the outset they have violently cracked down on the popular uprising, and have used increasingly heavy weaponry in doing so. Their forceful suppression of the anti-regime uprising can, again, be explained by the patrimonial nature of the Syrian military establishment, which is dominated by family, tribal and sectarian ties to the Syrian leadership, and the relatively weak relationship between the Syrian military, at least in its higher ranks, and the population at large.

Moreover, in contrast to Libya or Yemen, and similar to Bahrain, the Syrian army has (thus far) been largely able to maintain its coherence when confronted with the anti-regime movement, even though there have been some defections. As in the case of Bahrain, this can be accounted for by the fact that the Syrian armed forces, despite their patrimonial characteristics, 
are still a more coherent and institutionalised body than the 'patchwork' militaries of Libya or Yemen. In addition, a key factor behind the unity and coherence of the militaries of both Syria and Bahrain in putting down the uprising has arguably been their sectarian bias and the fact that they have perceived themselves as being involved in a sectarian struggle for their own survival. ${ }^{169}$ This also explains why Syria has seen at least some defections, whereas in Bahrain this phenomenon seems to have been entirely absent: while in the latter case the entire military apparatus is characterised by a sectarian bias, in the former this bias has been more limited in that it concerns primarily the higher echelons and most elite units of the armed forces. 


\section{CONCLUSION}

Armed forces have traditionally been key players in the political systems of Middle Eastern and North African states, and it is thus hardly surprising that they have also played a crucial role in the profound transformations which are currently sweeping across much of the Arab world. Indeed, it can be argued that the attitude and response of the armed forces to pro-reform movements have been a critical factor in the success or failure of these uprisings. To be sure, anti-regime protests have been popular, grassroots movements driven by widespread dissatisfaction with economic mismanagement and political oppression. Yet the role of the armed forces has been crucial in determining whether or not authoritarian regimes were eventually overthrown. Even though the ousting of Ben Ali and Mubarak cannot be described as military coups in the traditional sense, as the uprisings against them were neither initiated nor spearheaded by the armed forces, ${ }^{170}$ in both countries it can be argued that it was the siding of the military with the protesters which ultimately led to the downfall of these leaders. In Libya too, the popular uprising against the Qaddafi regime could have hardly been successful without the siding of at least part of the military with the anti-regime movement. Conversely, the fact that other long-standing autocrats in countries such as Bahrain, Syria or Yemen have (so far) been able to hang on to power despite massive protests has been largely due to the continuous support from the armed forces, at least of their most important elements, that these regimes have enjoyed. 


\section{Arab uprisings and armed forces: Comparative perspective}

In explaining armed forces' responses to pro-reform or anti-regime uprisings, this paper has highlighted the importance of two main factors: the degree of institutionalisation/patrimonialism of the military apparatus, and its relationship to society at large (with the main focus on the first factor). In both Tunisia and Egypt a (relatively) high level of institutionalisation - higher in Tunisia than in Egypt - and a strong connection between the armed forces and the population have led to (relative) openness to reform movements - again with the Tunisian military showing a greater degree of openness than its Egyptian counterpart. In Libya and Yemen the military has lacked any level of institutionalisation and has been highly fragmented, resulting in a fracturing of the armed forces when confronted with the popular uprising. In both countries the splintering of the military has been furthered by a combination of on the one hand highly patrimonial (elite) units intimately tied to the regime, and on the other hand elements of the military which are at least to some extent anchored in society at large. In Bahrain and Syria a patrimonial military apparatus with a weak relationship to the population - weaker in Bahrain than in Syria - has led to a forceful crackdown on pro-reform movements. The stronger relationship between the armed forces and society in Syria compared to Bahrain - taking into account that the former uses general conscription and that the sectarian bias of Syria's army is not as pronounced as in Bahrain - has been manifest in defections from the Syrian armed forces, even though these have so far remained relatively limited. Table 4 summarises these findings.

Comparing the six case studies, it can be argued that the cases of Tunisia, Egypt and Bahrain are the most clear and unambiguous. In these three countries, the two factors identified here have 'pulled' in the same direction, towards openness to pro-reform movements in Tunisia and Egypt, and towards resistance in the case of Bahrain, with the armed forces maintaining their unity in all three countries. The response of the armed forces to the popular uprising in Libya, Yemen and Syria has been more ambivalent, as at least to some extent the two factors have worked in opposite directions. As a consequence, in these three countries the coherence of the armed forces has been challenged by the popular upheavals, although to vastly different degrees: in both Libya and Yemen 
Table 4: Characteristics of armed forces and responses to pro-reform movements in Tunisia, Egypt, Libya, Bahrain, Yemen and Syria

\begin{tabular}{|l|c|c|c|c|c|c|}
\hline & Tunisia & Egypt & Libya & Yemen & Bahrain & Syria \\
\hline $\begin{array}{l}\text { Type of civil- } \\
\text { military } \\
\text { relations }\end{array}$ & $\begin{array}{l}\text { Autocratic } \\
\text { officer- } \\
\text { politician } \\
\text { regime }\end{array}$ & $\begin{array}{l}\text { Autocratic } \\
\text { officer- } \\
\text { politician } \\
\text { regime }\end{array}$ & $\begin{array}{l}\text { Dual } \\
\text { military } \\
\text { regime }\end{array}$ & $\begin{array}{l}\text { Autocratic } \\
\text { officer- } \\
\text { politician } \\
\text { regime }\end{array}$ & $\begin{array}{l}\text { Tribally } \\
\text { dependent } \\
\text { monarchy }\end{array}$ & $\begin{array}{l}\text { Autocratic } \\
\text { officer- } \\
\text { politician } \\
\text { regime }\end{array}$ \\
\hline $\begin{array}{l}\text { Institutionali- } \\
\text { sation of } \\
\text { armed forces }\end{array}$ & High & Medium & $\begin{array}{l}\text { Very low: } \\
\text { fragmented } \\
\text { military }\end{array}$ & $\begin{array}{l}\text { Very low: } \\
\text { fragmented } \\
\text { military }\end{array}$ & Low & Low \\
\hline $\begin{array}{l}\text { Relationship } \\
\text { to society at } \\
\text { large }\end{array}$ & Strong & Strong & $\begin{array}{l}\text { Weak/ } \\
\text { strong }\end{array}$ & $\begin{array}{l}\text { Weak/ } \\
\text { strong }\end{array}$ & Weak & Medium \\
\hline $\begin{array}{l}\text { Response to } \\
\text { pro-reform } \\
\text { movements }\end{array}$ & Openness & $\begin{array}{l}\text { Openness } \\
\text { (relative) }\end{array}$ & Fracturing & Fracturing & Resistance & $\begin{array}{l}\text { Resistance } \\
\text { (with some } \\
\text { defections) }\end{array}$ \\
\hline
\end{tabular}

the military has effectively broken up, practically resulting in a civil war, whereas Syria has seen defections, although so far only on a rather small scale.

Overall, the model proposed here can be said to explain armed forces' responses to pro-reform movements, at least as far as the three basic scenarios of openness, resistance and fracturing are concerned. Arguably, the main shortcoming of the explanatory framework is that it is rather crude, treating the military as a 'black box' without looking into its internal tensions and contradictions. Such internal divisions have most likely been present within the armed forces of most if not all countries examined here, not only in those cases where the military has effectively fractured when confronted with the anti-regime movement. A more refined analysis of the role of the armed forces during the Arab uprisings should thus look at the contradictions and struggles within the armed forces, for example between different hierarchical levels and different military units, and the ways in which these ultimately shaped the military's response to pro-reform movements.

Similarly, the preceding analysis has provided only an introductory account of the relationship between the armed forces and society, confining itself to basic elements such as the use of general conscription, the reliance on foreign fighters or the sectarian composition of the military. 
Also in this respect, a more refined analysis could examine in more detail the make-up of the armed forces of Arab countries, taking into account social, ethnic, tribal, religious and other factors at all levels of the military hierarchy, and how these have affected their reaction to the popular uprisings.

Finally, this paper has shown the relative usefulness but also the limitations of Kamarava's typology of civil-military relations in explaining the response of armed forces to anti-regime movements. ${ }^{171}$ The typology seems quite good at predicting the responses of armed forces to proreform movements in what he has called 'tribally dependent monarchies' and 'dual military regimes'. In these two types of regimes the military is likely to oppose anti-regime movements strongly, at least as far the most elite units are concerned. However, in countries which Kamrava has classified as 'autocratic officer-politician' regimes, which in his analysis include countries such as Tunisia, Egypt, Yemen and Syria, a broad array of responses to the popular uprisings can be found, ranging from support to fracturing and firm opposition to the pro-reform movements. As suggested above, what can ultimately account for armed forces' responses to the popular upheavals is less Kamarava's categorisation as such but rather the two key factors identified here: the degree of institutionalisation of the military and the strength of its relationship to society at large. And these two factors can vary considerably among countries which Kamarava classifies as 'autocratic officer-politician regimes', resulting in different types of responses to pro-reform movements.

\section{Towards democratic civil-military relations?}

Given the profound transformations currently sweeping across the Middle East and North Africa, what are the prospects of establishing more democratic civil-military relations in the region, i.e. subjecting the armed forces to the control of democratically elected civilian authorities? Addressing this issue in detail is beyond the scope of this paper, but at least a few brief remarks can be made, in particular with regard to those countries where authoritarian regimes, or at least their leaders, have thus far been overthrown, i.e. Tunisia, Egypt and Libya.

The first point is that one if not the main obstacle to subjecting the armed forces - or the security sectors more generally - of Arab countries to 
civilian and democratic control has long been seen in the absence of democratic political systems. Even though some countries of the region have made efforts to reform their security forces in recent years, it has been commonly agreed that without true democratic change of the political systems as a whole, such reforms at best remain very limited in scope. ${ }^{172}$ While at this point it is still unclear if and to what extent the countries of the Middle East and North Africa will move towards genuinely democratic systems, such a transformation would arguably remove the most important impediment to profound reforms of these countries' security forces. In this sense, the current upheavals could potentially provide a unique opening for achieving truly democratic and civilian control and accountability of these countries' armed forces (and security sectors more generally).

On the other hand, and perhaps ironically, the fact that in countries such as Tunisia and Egypt the military has played such a crucial role in overthrowing authoritarian leaders might itself prove to be an obstacle to moving towards more democratic civil-military relations. Having sided with the population against the regimes (or at least their leaders), and thus being able to take credit for the success of the popular uprisings, the armed forces of these countries might be reluctant to see their powers curtailed within a more democratic political system in which they would fall under the authority of civilian and democratically elected authorities. The great popularity the armed forces of Tunisia and Egypt are currently enjoying as a result of their role during these countries' revolutions might help them resist efforts to subject them to more stringent controls.

However, while this basic dilemma might be present in both Tunisia and Egypt, the two countries nevertheless differ significantly when it comes to the prospects of achieving more democratic civil-military relations. More optimism in this respect is certainly warranted in the case of Tunisia. As mentioned above, Tunisia already has a tradition of a largely apolitical army. While under Ben Ali the army was not subject to democratic control, given the absence of a wider democratic system, it was nevertheless subject to control by a civilian government, including a civilian minister of defence. There are thus grounds to expect that the Tunisian army will not fundamentally oppose reforms towards more democratic civil-military relations, which would arguably not radically alter its role and status within the Tunisian political system. ${ }^{173}$ 
Nevertheless, even in Tunisia there are reasons to be cautious. As mentioned previously, there are at least some indications that the Tunisian military might seek more political influence in the post-Ben Ali period. Indeed, a less than sanguine but not entirely implausible interpretation of the Tunisian army's role during the revolution might be that it toppled Ben Ali mainly to put an end to its own relative marginalisation within the Tunisian political system, and in a sense to correct its relatively anomalous status among Arab armies. In a worst-case - although perhaps not very likely - scenario, the armed forces might take advantage of the current political instability in the country, including fears of an 'Islamist takeover', and assume a stronger political role.

Egypt is certainly a much more complex case than Tunisia, and there are clearly more grounds for scepticism given the military's long-standing relationship to the authoritarian regime when it comes to the armed forces' acceptance of true democratic reforms. Even though during the Egyptian uprising the military sided with the pro-democracy protesters against the president in the end, in this case as well a pessimistic interpretation of its behaviour during the uprisings is not without plausibility: the army might have decided to shed its former supreme commander mainly in order to maintain its privileged status within the Egyptian political and economic system.

In the current transitional period, the Egyptian military and the ruling Supreme Council of the Armed Forces have - as argued above - generally shown a rather mixed attitude towards the pro-democracy movement, and the ways in which their position within the Egyptian political system will evolve in the long run are thus difficult to foresee. Among (traditional and emerging) political actors in Egypt, there is currently a broad range of opinions regarding the role of the armed forces within the country's future political system. It is noteworthy that, since the fall of Mubarak, support for a strong political role for the military has come mainly from liberal forces. This position sees the army as a guardian of the state's civil foundation and a means to prevent Islamists from using their potential majority in upcoming elections to turn Egypt into a theocratic state. On the other hand, Islamists as well as some leftists and liberals, including presidential hopeful Mohammed El-Baradei, have opposed giving the army significant political powers, fearing that this could lead to a situation similar to Turkey. ${ }^{174}$ 
As for the position of the Egyptian armed forces themselves, again mixed signals can be detected. When in July 2011 the Supreme Council of the Armed Forces announced that it would issue a 'declaration of basic principles' which would 'guide' the writing of a new constitution, initial drafts reportedly included provisions assigning the military wide-ranging powers, including a mandate to intervene in Egyptian politics to protect national unity and the secular character of the state. They also shielded military budgets and economic activities from public or parliamentary scrutiny. ${ }^{175}$ Subsequent drafts, however, arguably as a result of public criticism, omitted provisions on the role of the army, presumably leaving this to the drafting of the actual constitution by a future parliament. ${ }^{176}$ More recently, General Mohammed Al-Assar, an influential member of the Supreme Council of the Armed Forces, declared on a visit to the United States that the future role of the Egyptian military would not be defined by the military itself, but rather by the new Egyptian parliament, and that the military would accept any role assigned to it, no matter how narrow or broad. ${ }^{177}$ While the question of the future political role of the Egyptian army thus remains an open one, if past trends offer any clues for the future, two broad assumptions can be made. First, the military will be willing to withdraw (further) from the forefront of politics, also giving up its longstanding monopoly (or veto power) over the presidency. And second, it will vehemently resist outside scrutiny and inference in its business undertakings. ${ }^{178}$

Finally, turning to Libya, predictions regarding the future role of the military are even more difficult to make, given the particular nature of the political system under Qaddafi and the fact that after the overthrow of the former regime, the country is only starting to emerge from a six-monthslong civil war. While Libya's National Transitional Council, which is currently running the country, has committed itself to establishing a democratic system, Libya in contrast to Tunisia or Egypt almost entirely lacks any functioning state institutions upon which a new political order could be constructed. Moreover, its military and security forces seem to have largely collapsed as a result of the conflict. Libya's entire political system, including its security structures, thus needs to be practically built from scratch. Needless to say this offers both a challenge and an opportunity - a challenge in that the task is much more momentous than in Tunisia or Egypt, and an opportunity in that the path towards a more democratic 
system, including more democratic civil-military relations, should not be as burdened as elsewhere by remnants of the previous authoritarian regime.

To conclude, the analysis in this paper overall highlights the continued relevance of the study of the role of armed forces and civilmilitary relations in the Arab world. Just as the political systems of Middle Eastern states cannot be adequately understood without taking into consideration the crucial part played by the military therein, so would any account of the current Arab uprisings which overlooks the role of the armed forces be seriously incomplete. As shown in this paper, in all Arab countries experiencing broad-based pro-reform movements, the military has been a key actor in responding to this challenge, even though, depending on the characteristics of the armed forces, their responses have varied widely across the region. The same goes for the future evolution of Arab political systems: while the extent to which Arab countries will move towards more democratic forms of rule remains an open question at this stage, it is clear that the status and role of the armed forces within the future political systems in the region will be a key issue which will have to be addressed in such a transformation. 


\section{NOTES}

1 Joshi Shashank, 'Arab Spring: The Nature of Armies Decisive in Revolutions', BBC News, 28 June 2011.

2 This echoes the work of Theda Skocpol on social revolutions. She has inter alia highlighted the fact that while social revolutions are usually driven by widespread popular discontent with the existing regime, it is only in those cases where state leaders and their security forces lose the ability (or willingness) to suppress an uprising that a revolution will ultimately succeed. See Theda Skocpol, States and Social Revolutions. A Comparative Analysis of France, Russia and China (Cambridge: Cambridge University Press, 1979).

3 While Western countries have generally been supportive of the pro-democracy movements in Arab countries, it should also be noted that at least in the case of the Tunisian revolution, European countries were rather slow to react to the popular uprising, and France even offered assistance to Ben Ali in the final days of his reign to quell the anti-government riots.

4 See e.g. Arend Lijphart, 'Comparative Politics and the Comparative Method', American Political Science Review, vol. 65, no. 3, 1971, pp. 682-693.

5 See e.g. Murray Andrew Faure, 'Some Methodological Problems in Comparative Politics', Journal of Theoretical Politics, vol. 6, no. 3, 1994, pp. 307-322.

6 Samuel Huntington, The Soldier and the State. The Theory and Politics of Civil-Military Relations (Cambridge, MA: Harvard University Press, 1957).

7 Morris Janowitz, The Professional Soldier: A Social and Political Portrait (Glencoe, IL: Free Press, 1960).

8 Samuel F. Finer, The Man on Horseback. The Role of the Military in Politics (New Brunswick and London: Transaction Publishers, 2006).

9 Kees Koonings and Dirk Kruijt, 'Military Politics and the Mission of Nation Building', in Kees Koonings and Dirk Kruijt (eds), Political Armies. The Military and Nation Building in the Age of Democracy (London and New York: Zed Books, 2002), p. 19.

10 Amos Perlmutter, Political Roles and Military Rulers (London: Frank Cass, 1981), pp. 1619.

11 Mehran Kamrava, 'Military Professionalization and Civil-Military Relations in the Middle East', Political Science Quarterly, vol. 115, no. 1, 2000, pp. 67-92.

12 See e.g. Eliezer Be'eri, Army Officers in Arab Politics and Society (New York: Praeger, 1969); George M. Haddad, Revolutions and Military Rule in the Middle East, vols 1-3 (New York: Robert Seller, 1965); Perlmutter, note 10 above. Perlmutter, note 10 above, pp. 25-35.

Steven A. Cook, Ruling But Not Governing. The Military and Political Development in Egypt, Algeria and Turkey (Baltimore, MD: Johns Hopkins University Press, 2007).

Barry Rubin, 'The Military in Contemporary Middle East Politics', in Barry Rubin and Thomas A. Keaney (eds), Armed Forces in the Middle East. Politics and Strategy (London and New York: Routledge, 2002), pp. 1-22.

Eva Bellin, 'The Robustness of Authoritarianism in the Middle East. Exceptionalism in Comparative Perspective', Comparative Politics, vol. 36, no. 2, 2004, pp. 139-157; Risa 
Brooks, Political-Military Relations and the Stability of Arab Regimes, Adelphi Paper No. 324 (Oxford: Oxford University Press, 1998).

Kamrava, note 11 above, pp. 67-92. Kamrava also mentions a fourth category of civilmilitary relations in the Middle East, 'military democracies', which applies only to Israel and Turkey.

See e.g. Lahouari Addi, 'Army, State and Nation in Algeria', in Kees Koonings and Dirk Kruijt (eds), Political Armies. The Military and Nation Building in the Age of Democracy (London and New York: Zed Books, 2002), pp. 179-203; Ibrahim Karawan, 'Security Sector Reform and Retrenchment in the Middle East', in Alan Bryden and Heiner Hänggi (eds), Reform and Reconstruction of the Security Sector (Münster: LIT Verlag, 2004), p. 253.

Global Security, 'The Saudi Arabian National Guard', available at www.globalsecurity.org /military/world/gulf/sang.htm.

Kamrava, note 11 above, p. 83.

Bellin, note 16 above, p. 145.

Ibid., p. 146.

Ibid.

24 Among theorists of civil-military relations, as already mentioned, it was in particular Janowitz who advocated the use of conscription in order to ensure 'convergence' between the civilian and military realms.

The facts and figures in the boxes are drawn from IISS, Military Balance 2010 (London: International Institute for Strategic Studies, 2010) and the SIPRI Military Expenditure Database. The last item - estimated death toll - refers to both civilian and military casualties during the uprising. As far as possible, UN estimates were used. Kamrava, note 11 above.

L. B. Ware, 'The Role of the Tunisian Military in the Post-Bourgiba Era', Middle East Journal, vol. 39, no. 1, 1985, p. 37; L. B. Ware, Tunisia in the Post-Bourgiba Era. The Role of the Military in a Civil Arab Republic (Maxwell, AL: Air University Press, 1986), p. 47. Moreover, Ben Ali already occupied the post of prime minister when he removed Bourgiba from office. Michel Camau and Vincent Geisser, Le syndrome autoritaire. Politique en Tunisie de Bourgiba à Ben Ali (Paris: Presses de Sciences Politiques, 2003), p. 211.

In 200213 high-ranking officers of the Tunisian armed forces, including the army chief of staff, Brigadier General Abdelaziz Skik, were killed in a helicopter crash. There have been widespread suspicions in Tunisia that Ben Ali was behind the accident, attempting to purge the military of officers considered insufficiently loyal. These allegations have, however, recently been denied by the transition government which took power after Ben Ali's departure in January 2011. See 'Le ministère de la Défense dément la thèse du "complot"', Le Temps, 23 April 2011.

33 Camau and Geisser, note 29 above, pp. 205, 209; International Crisis Group, 'Soulèvements populaires en Afrique du Nord et au Moyen-Orient (IV): La voie tunisienne', Middle East/North Africa Report no. 106 (Tunis and Brussels: ICG, 28 April 2011), p. 11. 
Global Security, 'Tunisia: 'Conscription', available at www.globalsecurity.org/military/ world/tunisia/conscription.htm.

International Crisis Group, note 31 above, pp. 1-9.

'Le jour où Ben Ali a été renversé', Jeune Afrique, 14 January 2011; 'Tunisie: I'armée, acteur clé du changement en cours', Le Figaro, 14 January 2011.

'Rachid Ammar, homme fort de la Tunisie: L'armée ne tire pas', Rue89, 16 January 2011; 'L'armée tunisienne sort grandie de la crise politique', Le Dépêche, 17 January 2011; 'Rachid Ammar, le centurion du peuple', Le Figaro, 21 January 2011; 'Tunisie: la Grande Muette a dit "non"”, Jeune Afrique, 24 January 2011.

'L'armée tunisienne remporte le soutien populaire', Magharebia, 28 January 2011.

See note 34 above.

'Journée du 14 janvier version Grira', Tunivisions, 9 March 2011; International Crisis Group, note 31 above, p. 11.

'L'amiral Lanxade: C'est l'armée qui a lâché Ben Ali', Le Parisien, 16 January 2011; 'Tunisie: L'armée a lâché Ben Ali', Le Monde, 16 January 2011. A somewhat different version of events on Ben Ali's final days has also emerged, according to which the head of Ben Ali's Presidential Guard, Ali Seriati, is said to have played a key role in his departure, possibly with the objective of taking over power himself. See e.g. 'Tunisie: que mijotait Ali Seriati?', Jeune Afrique, 28 March 2011; Tunivisions, note 38 above. Seriati was arrested on the day of Ben Ali's departure on conspiracy charges.

'Tunis Gun Battles Erupt after Ben Ali Aide Arrested', BBC News, 16 January 2011; 'Confusion, Fear and Horror in Tunisia as Old Regime's Militia Carries on the Fight', The Guardian, 16 January 2011.

See e.g. 'La crainte de l'Armée nationale tunisienne a-t-elle commencé suite au discours de Chebbi?', Webdo, 3 March 2011; 'Tunisie: L'armée finalement au pouvoir?', Le Post, 25 January 2011.

'Opinion - Rachid Ammar préparerait-il son arrivée au pouvoir?', Webdo, 4 March 2011; 'Biographies des nouveaux gouverneurs', La Presse, 21 February 2011; 'How the Army Is Cracking Down on the Interior Ministry', Africa Intelligence, no. 955, 17 January 2011.

'De fausses informations qui portent préjudice à l'ordre public', La Presse, 6 May 2011; 'Tunisie: I'armée nationale n'est pas intéressée par le pouvoir', Investir En Tunisie, 10 May 2011.

'Apparition du Général Rachid Ammar place de la Kasbah', Tunivisions, 24 January 2011.

Mohamed Kadry Said and Noha Bakr, 'Egypt Security Sector Reform', Arab Reform Initiative Thematic Studies, February 2011, available at www.arab-reform.net/ spip.php? article4180. Dissatisfaction with cronyism at the highest echelons of the army, and in particular with the appointment of Mubarak loyalists to top-level positions, was described in a leaked US embassy cable of 2008. See US Embassy in Cairo, 'Academics See the Military in Decline But Retaining Strong Influence', 23 September 2008 (Wikileaks - 08CAIRO2091).

Tewfik Aclimandos, 'Egyptian Army: Defining a New Political and Societal Pact', Al Jazeera Centre for Studies, 24 February 2011, available at www.aljazeera.net/mritems/ streams/2011/2/24/1_1044099_1_51.pdf.

Kamrava, note 11 above. 
Cook, note 14 above, pp. 63-92; Imad Harb, 'The Egyptian Military in Politics: Disengagement or Accommodation?', Middle East Journal, vol. 57, no. 2, 2003, pp. 269290.

While in the 1960s the Egyptian cabinet was composed of between 41 per cent and 66 per cent of military officers, under Mubarak this figure dropped to around 10 per cent. Moreover, the number of provincial governors with a military background declined significantly after the 1960s. See Mark N. Cooper, 'The Demilitarization of the Egyptian Cabinet', International Journal of Middle East Studies, vol. 14, no. 2, 1982, pp. 203-225; Maye Kassam, Egyptian Politics. The Dynamics of Authoritarian Rule (Boulder, CO: Lynne Rienner Publishers, 2004), p. 40.

Youssef H. Aboul-Enein, 'Examining the Reconstruction of Egyptian Morale During the Aftermath of the 1967 Six Day War: An Arab Perspective', Air and Space Power Journal, 4 February 2002.

Tewfik Aclimandos, 'Reforming the Egyptian Security Services. Re Review of the Press, Conventional Wisdom and Rumours', Arab Reform Initiative Thematic Study, 8 June 2011, p. 2, available at www.arab-reform.net/IMG/pdf/SSR_EGYPT_ACLIMANDOS_ edit_ENG_final.pdf. The military leadership's 'frustration' and 'disenchantment' with the prospect of Gamal Mubarak being promoted to the office of the presidency is also described in US cables leaked by Wikileaks. See US Embassy Cairo, 'Presidential Succession in Egypt', 14 May 2007 (Wikileaks - 07CAIRO1417). Ken Stier, 'Egypt's Military-Industrial Complex', The Times, 9 February 2011; Marian Wang, 'Egypt's Post-Mubarak: Key Facts on the Military's Long-Standing Role', Pro Publica, 11 February 2011. Robert Springborg, 'Military Elites and the Polity in Arab States', Development Associates Occasional Paper no. 2 (Arlington, VT: Development Associates, 1998). Cassandra, 'The Impending Crisis in Egypt', Middle East Journal, vol. 49, no. 1, 1995, p. 23. Springborg, note 53 above, pp. 8-9. Aclimandos, note 46 above; Brooks, note 16 above, p. 24. 'Army Pledges No Use of Force During Tuesday's Protests', Almasry/Alyoum, 31 January 2011; 'Military Calls Egyptian People's Demands “Legitimate"', AFP, 31 January 2011. Moaaz Elzoughby, 'The Dynamics of Egypt's Protest: An Inside View', Arab Reform Brief, February 2011, p. 3, available at www.arab-reform.net/IMG/pdf/ARB_46_Egypt-_MElzoughby-Eng-.pdf; 'Protesters Welcome Army, Sing "Long Live Egypt", Reuters, 28 January 2011. '15 Egypt Army Officers Join Protesters', Reuters, 11 February 2011. International Crisis Group, 'Popular Protest in North Africa and the Middle East (I): Egypt Victorious?', Middle East/North Africa Report no. 101 (Cairo and Brussels: ICG, 24 February 2011), p. 16. In Egypt this episode is now commonly referred to as the 'Battle of the Camel'. 'Violence Flares in Cairo Square', Aljazeera, 3 February 2011; 'Bullets, Firebombs and Rocks: The Violent Struggle for Cairo's Tahrir Square', The Times, 2 February 2011. The event, however, seems to have swayed public opinion and state media coverage in favour of the demonstrations. See Elzoughby, note 58 above, p. 4. 
'Army Backs Mubarak in Second Statement', Almasry/Alyoum, 11 February 2011; 'Egyptian Army Backs Hosni Mubarak and Calls for Protesters to Go Home', The Guardian, 11 February 2011; 'Egypt: Military Shifts Posture Closer to Mubarak?', Stratfor, 11 February 2011.

Egyptian Armed Forces, Communiqué No. 1, 10 February 2011. The Supreme Council of the Armed Forces consists of 20 senior officers of the Egyptian military. It meets regularly, as well as in times of crisis, and is normally chaired by the president of Egypt. See e.g. Be'eri, note 12 above, p. 256.

Egyptian Armed Forces, Communiqué No. 2, 11 February 2011.

Human Rights Watch, 'Egypt: Investigate Arrests of Activists, Journalists' (Cairo: HRW, 9 February 2011); 'Protesters in Egypt Recount Their Experiences of Military Detainment, Army Denies Torture', Al Ahram, 17 March 2011.

'Egypt's Army Helped Oust President Mubarak', BBC News, 19 February 2011; 'Analysis: Military Coup Was Behind Mubarak's Exit', Associated Press, 11 February 2011; 'Army and Presidency at Odds - Says Former Intelligence Official', Al Ahram, 11 February 2011; 'Quiet Military Coup Was Behind Mubarak's Resignation', Haaretz, 13 February 2011.

Egyptian Armed Forces, Communiqué No. 4, 12 February 2011.

'2 Protesters Killed in Egypt's Tahrir Square', New York Times, 9 April 2011; 'Reuters Reports Two Deaths; Army Says No Live Rounds Fired', Al Ahram, 9 April 2011.

This has been evidenced for example by the jailing of an Egyptian blogger for three years for allegedly insulting the armed forces. See 'Egyptian Blogger Jailed for Three Years', Aljazeera, 11 April 2011. In April 2011 one member of the Supreme Council of the Armed Forces declared in a televised interview that in the 'new Egypt' freedom of expression was guaranteed, but only 'so long as it is respectful and does not question the armed forces' (quoted in 'Egypt's Revolution: Staggering in the Right Direction', The Economist, 14 April 2011).

Human Rights Watch, 'Egypt: Military Intensifies Clampdown on Free Expression' (New York: HRW, 17 August 2011).

'What Do Egyptians Want?', Al Ahram Weekly, no. 1046, 5-11 May 2011.

This assessment contrasts somewhat with the official view of the Egyptian army, which since the resignation of Mubarak has put great emphasis on the fact that it sided with the protesters against the Mubarak regime from the outset of the demonstrations. See 'The Army's Side of the Story', Al Ahram Weekly, no. 1043, 14-20 April 2011.

For an overview of the Libyan security sector see Hanspeter Mattes, 'Challenges to Security Sector Governance in the Middle East: The Libyan Case', Conference Paper (Geneva: DCAF, 2004).

Kamrava, note 11 above.

Mattes, note 75 above, pp. 13-17; Hanspeter Mattes, 'The Rise and Fall of the Revolutionary Committees', in Dirk Vanderwalle (ed.), Qadhafi's Libya, 1969-1994 (New York: St Martin's Press, 1995), pp. 89-112; Dirk Vanderwalle, A History of Modern Libya (Cambridge: Cambridge University Press, 2006), p. 149. The main tribes which have supported the Qaddafi regime include the Qadadfa, Qaddafi's own tribe, the Megharha and the Warfalla, which is Libya's largest tribe.

'Son's Unit May Be One of Gaddafi's Last Lines of Defense', Reuters, 24 February 2011. 
Leaked US cables have described the Khamis Brigade as 'the most well-trained and wellequipped force in the Libyan military' and 'the most important military and security elements of the regime'. See US Embassy Tripoli, 'Libyan Succession: Qadhafi Orchestrating the Boys: High Wire Act?', 19 November 2009 (Wikileaks - 09TRIPOLI924). See also George Joffé, 'Libya: The Internal Dynamics of Collapse', Royal African Society, 23 February 2011, available at www.royalafricansociety.org/component/content/ 812.html?view=article.

'Among Libya's Prisoners: Interviews with Mercenaries', The Times, 22 February 2011; 'Gadhafi's Military Muscle Concentrated in Elite Units', NPR, 10 March 2011. Mattes, note 75 above, pp. 4-5. world/libya/militia.htm.

William J. Foltz, 'Libya's Military Power', in René Lemarchand (ed.), The Green and the Black (Indianapolis, IN: Indiana University Press, 1988), p. 57.

Anthony H. Cordesman, A Tragedy of Arms. Military and Security Developments in the Maghreb (Westport, CT: Praeger, 2002), p. 220; Kenneth Pollack, Arabs at War. Military Effectiveness, 1948-1991 (Lincoln, NE: University of Nebraska Press, 2002), p. 360; Foltz, ibid.

'Worrisome Signs of a Fractured Libyan Army', Stratfor, 21 February 2011.

'Libyan Unrest Spreads to Tripoli as Benghazi Erupts', Reuters, 20 February 2011.

'Battle at Army Base Broke Gadhafi Hold in Benghazi', Associated Press, 21 February 2011; Reuters, ibid.

'A Family at War', Africa Confidential, vol. 52, no. 7, 1 April 2011; 'In Eastern Libya, Defectors and Volunteers Build Rebel Army', The Atlantic, 4 March 2011.

'Libyan Rebels Speak Out', Magharebia, 29 April 2011.

'Khamis Qaddafi Takes the Offensive', Intelligence Online, no. 637, 17 March 2011; 'Khamis Ghadafi: The Agent of Fear', Afrol News, 23 February 2011.

On 21 February two Libyan fighter jets landed in Malta. Their pilots reportedly defected after being asked to bomb protesters in Benghazi. See 'Two Libyan Fighter Pilots Defect to Malta', Times of Malta, 22 February 2011.

'UN Scales Up Relief Assistance in Misrata as Death Toll Reaches 300', UN News and Media, 26 April 2011, available at www.unmultimedia.org/radio/english/2011/04/unscales-up-relief-assistance-in-misrata-as-death-toll-reaches-300/; UN Security Council Resolution 1970, 15 March 2011.

Some human rights organisations have put the figure of foreign mercenaries used by Qaddafi at between 6,000 and 30,000, while others have suggested the number was in the hundreds. See 'Libyans, Black-Africans and Gaddafi's Divisive Power Struggle', Afrik News, 8 March 2011; 'Experts Disagree on African Mercenaries in Libya', VOA News, 1 March 2011; 'Libya: Gaddafi Turns to Son's Special Forces and Foreign Mercenaries', Afrik News, 25 February 2011.

'Witnesses Say African Mercenaries Have Been Captured in Libya', France 24, 21 February 2011.

100 'Ex-Qaddafi Colonel Says the Regime Is Crumbling', The Sunday Times (Malta), 14 August 2011. 
'Libyan Dictator Gadhafi Ordered Rapes to "Humiliate" His Enemies', ABC News, 9 June 2011; 'Gaddafi Faces New ICC Charges for Using Rape as Weapon in Conflict', The Guardian, 9 June 2011.

These are the estimates of the National Transitional Council which took over power after the downfall of Qaddafi, and have not yet been independently verified. See 'Libyan Estimate: At Least 30,000 Died in the War', Associated Press, 8 September 2011. Kamrava, note 11 above.

104 Global Security, 'Yemen: Yemen Army', available at www.globalsecurity.org/military/ world/yemen/army.htm; Michael Horton, 'Special Report from Yemen: The Looming Threat of Tribal War', Jamestown Foundation, 1 March 2011, available at www.jamestown.org/single/?no_cache=1\&tx_ttnews\%5Btt_news\%5D=37583. International Crisis Group, 'Popular Protest in North Africa and the Middle East (II): Yemen Between Reform and Revolution', Middle East/North Africa Report no. 102 (Sanaa and Brussels: ICG, 10 March 2011), p. 15; Ginny Hill, 'Yemen: Fear of Failure', Chatham House Briefing Paper (London: Royal Institute of International Affairs, 2008), p. 3. A list of some of the most important military commanders who are closely related to President Saleh can be found at Global Security, 'Yemen: Nepotism', available at www.globalsecurity.org/military/world/yemen/nepotism.htm. Global Security, 'Yemen: Intelligence Agencies', available at www.globalsecurity.org/ intell/world/yemen/index.html. Derek Miller, 'Demand, Stockpiles and Social Controls: Small Arms in Yemen', Small Arms Survey Occasional Paper no. 9 (Geneva: Small Arms Survey, 2003). Sarah Philips, 'What Comes Next in Yemen? Al-Qaeda, Tribes and State-Building', Carnegie Paper no. 107 (Washington DC: Carnegie Endowment for International Peace, 2010), p. 2.

109 Paul K. Desch, 'The Tribal Factor in the Yemeni Crisis', in Jamal al-Suwaidi (ed.), The Yemeni War of 1994: Causes and Consequences (Abu Dhabi: Emirates Centre for Strategic Studies and Research, 1995), pp. 33-55.

110 International Crisis Group, note 100 above, p. 5; Elham M. Manea, 'Yemen, the Tribe and the State', paper presented at International Colloquium on Islam and Social Change, Lausanne, 10-11 October 1996, available at www.al-bab.com/yemen/soc/manea1.htm.

111 According to Transparency International's corruption index, in 2009 Yemen occupied rank 154 out of 180 countries.

112 International Crisis Group, note 100 above, p. 15.

113 Global Security, 'Yemen: Corruption', available at www.globalsecurity.org/military/ world/yemen/corruption.htm.

114 Global Security, note 99 above.

115

Global Security, 'Yemen: Yemen Military', available at www.globalsecurity.org/military/ world/yemen/military-intro.htm.

International Crisis Group, note 100 above, p. 5.

'Major Yemen Tribes Join Protesters', Aljazeera, 26 February 2011.

International Crisis Group, note 100 above, p. 6.

'Yemen in Crisis: A Special Report', Stratfor, 21 March 2011.

Ibid. 
141

142

143

144

\section{(} Syrian People's Slow Motion Revolution', Middle East/North Africa Report no. 108 (Damascus and Brussels: ICG, July 2011), pp. 1-3. Syria's sectarian/ethnic composition is

'Army Splits in Yemen, Crisis Escalates', Stratfor, 21 March 2011.

'Top Army Commanders Defect in Yemen', Aljazeera, 21 February 2011.

'Yemen Showdown Looms as Army Loyalties Divide', The Guardian, 22 March 2011; Aljazeera, ibid.

'Five Killed in Shelling Near Yemen Tribal Chief Home - Source', AFP, 24 May 2011; 'Heavy Clashes Erupt in Yemen Capital, 21 Dead', Reuters, 24 May 2011.

'Yemen: Injured President Saleh Heads to Saudi Arabia for Medical Treatment', The Guardian, 4 June 2011.

'Yemenis Feel Breeze of War', Yemen Post, 18 June 2011.

Human Rights Watch, 'Yemen: Protester Killings Show Perils of Immunity Deal' (Geneva: HRW, 20 September 2011); Human Rights Watch, 'UN Human Rights Council: Yemen Resolution Falls Far Short' (Geneva: HRW, 1 October 2011.

Kamrava, note 11 above.

Ellen Laipson, Emilie El-Hokayem, Amy Buenning Sturm and Wael Alzayat, 'Security Sector Reform in the Gulf' (Washington DC: Henry L. Stimson Center, May 2006), p. 26; Global Security, 'Bahrain: Bahraini Forces', available at www.globalsecurity.org/military/ world/gulf/bahrain-mil.htm.

Rannie Amiri, 'Monarchy vs Democracy in Bahrain', Islamic Insights, 13 September 2010. Ibid.

International Crisis Group, 'Popular Protests in North Africa and the Middle East (III): The Bahrain Revolt', Middle East/North Africa Report no. 105 (Brussels: ICG, 6 April 2011) p. 4; 'Bahrain Security Forces Accused of Deliberately Recruiting Foreign Nationals', The Guardian, 17 February 2011.

International Crisis Group, ibid., p. 6.

'Bahrain Mourners Call for End to Monarchy', The Guardian, 18 February 2011.

'Bahrain Protests Banned as Military Tightens Grip', BBC News, 17 February 2011.

'Clashes Rock Bahraini Capital', Aljazeera, 17 February 2011; '5 Killed as Bahrain Cops Fire on Protesters', Daily Mirror, 18 February 2011.

The GCC Joint Defence Agreement was concluded in 2000 and provides a framework for collective defence and mutual military assistance based on the principle that any aggression against a member state would be considered as aggression against all the GCC states.

'Curfew Follows Deadly Bahrain Crackdown', Aljazeera, 16 March 2011.

'Bahrain Forces Quash Small Protests in "Day of Rage"', Reuters, 25 March 2011.

'Bahrain Hospital Attack: Physical Abuse and Humiliation of Doctors', The Telegraph, 20 March 2011.

'Bahrain Doctors Jailed for Treating Injured Protesters', The Guardian, 29 September 2011.

International Crisis Group, note 127 above, p. 8.

'Gulf States Send Forces to Bahrain Following Protests', BBC News, 14 March 2011.

International Crisis Group, 'Popular Protest in North Africa and the Middle East (VI): The 
estimated as 74 per cent Sunni, 12 per cent Alawite, 10 per cent Christian and 3 per cent Druze. Kamrava, note 11 above.

Before Hafez Al-Assad came to power in 1970, Syria witnessed numerous military coups and counter-coups. See e.g. Be'eri, note 12 above, pp. 55-75, 130-170.

Eyal Zisser, 'The Syrian Army on Domestic and External Fronts', in Barry Rubin and Thomas A. Keaney (eds), Armed Forces in the Middle East. Politics and Strategy (London and New York: Routledge, 2002), p. 113.

Although Alawites are an offshoot of Shia Muslims, they share many similarities with Christians.

Zisser, note 142 above, p. 119.

'Making Sense of the Syrian Crisis', Stratfor, 5 May 2011.

Pollack, note 84 above, p. 479.

Zisser, note 142 above, p. 121.

Ibid., p. 120.

'Syrian Racketeering in Lebanon', Middle East Transparent, 11 May 2001, available at www.metransparent.com/old/texts/syrian_racketeering_in_lebanon.htm; International Crisis Group, note 139 above, p. 29.

International Crisis Group, note 139 above, p. 28.

'The Military-Intelligence Shakeup in Syria', Middle East Intelligence Bulletin, vol. 4, no. 2, February 2002.

Eyal Zisser, 'Bashar Al-Assad's Gamble', Middle East Quarterly, fall 2006, pp. 61-66.

Human Rights Watch, 'Syria: Defectors Describe Order to Shoot Unarmed Protesters' (New York: HRW, 9 July 2011).

In these cities alone, more than 1,000 people are estimated to have been killed by security forces.

International Crisis Group, 'Popular Protest in North Africa and the Middle East (VII): The Syrian Regime's Slow Motion Suicide', Middle East/North Africa Report no. 109 (Damascus and Brussels: HRW, 13 July 2011), pp. 11-12.

'Helicopters Open Fire to Disperse Syrian Protesters', Reuters, 10 June 2011.

'Tank, Navy Attack on Syria's Latakia Kills 26: Witnesses', Reuters, 14 August 2011.

'UN Says Death Toll in Syrian Uprising Tops 3,000', Associated Press, 14 October 2011.

'Five Babies Born in Syrian Refugee Camps in Turkey Named "Recep Tayyip"', Today's Zaman, 3 July 2011; 'Lebanon Hosting Nearly 4,000 Syrian Refugees: UN', The Daily Star (Lebanon), 17 September 2011.

'Syrian Soldiers Shot for Refusing to Fire on Protesters', The Guardian, 12 April 2011; 'Deraa: A City Under a Dark Siege', Aljazeera, 29 April 2011.

The Free Syrian Army has its own Facebook page at www.facebook.com/ freesyrianarmy1.

International Crisis Group, note 155 above, p. 6; 'In Syria, Defectors Form Dissident Army in Sign Uprising May Be Entering New Phase', Washington Post, 26 September 2011; 'Army Storms Rastan as Defections Rise in Syria', Daily Star (Lebanon), 28 September 2011; 'Syrian Army Battles Defectors in Rebel Town as 11 More Protesters Killed', The Guardian, 2 October 2011. 
International Crisis Group, note 155 above, p. 13; 'Syrian Leader's Brother Seen as Enforcer of Crackdown', New York Times, 7 June 2011.

According to the International Crisis Group, it has been in particular the sectarian factor and the fact that the Syrian military has viewed the popular uprising through a 'sectarian prism', rather than 'genuine' loyalty to the regime, which explain its closing of ranks behind the regime. See International Crisis Group, note 139 above, p. 28.

170 Eliezer Be'eri, for instance, excludes 'uprisings not initiated by army officers' from his definition of 'military coups', even if they lead to the military taking power. See Be'eri, note 12 above, p. 244.

171 Kamrava, note 11 above.

172 See e.g. Bassma Kodmani and May Chartouni-Dubarry, 'The Security Sector in Arab Countries: Can It Be Reformed?', IDS Bulletin, vol. 40, no. 2, 2009, pp. 96-104.

173 At a recent seminar on the evolution of Arab armed forces after the revolutions, the former deputy chief of staff of the Tunisian army, Colonel Boubaker Benkraïem, highlighted the establishment of parliamentary control of the armed forces and the involvement of civil society in military issues as two priorities in the future development of the Tunisian armed forces. See 'La spécificité de I'Armée tunisienne', La Presse, 15 October 2011.

See e.g. 'Can Egypt's Military Be Trusted to Defend Democracy?', Al Masry/Al Youm, 6 July 2011; 'Egypt's Political Forces Battle for Constitution and Identity', Al Ahram, 22 August 2011; 'Egypt's Military Council Seeks to Ensure Power with Constitutional Guidelines', Stratfor, 17 July 2011.

175 'Egypt's Military Seeks Future Political Role', Al Masry/Al Youm, 19 July 2011; 'Egypt Military Aims to Cement Muscular Role in Government', New York Times, 16 July 2011.

176 'Political Groups Seek Consensus on Constitutional Clauses, Drop Special Role for Military', Al Masry/Al Youm, 19 July 2011; 'Military Is Left Out of Draft for Egyptian Rule', New York Times, 20 July 2011.

177 'Egypt's Military Vows to Abide by New Constitution', Inter Press Service, 25 July 2011.

178 One indication of the Egyptian army's willingness to give up its monopoly over the presidency can be seen in a military communiqué issued shortly after Mubarak stepped down, in which the Supreme Council of the Armed Forces declared that no member of the armed forces would stand as a candidate in the next presidential elections. The statement per se, however, does not seem to preclude its support for a candidate, who might even be a former member of the armed forces. See 'Egypt Military to Stay Out of Presidential Race, Supreme Council Announces', Al Ahram, 17 February 2011. 


\title{
Arab Uprisings and the Armed Forces: Between Openness and Resistance
}

\author{
Derek Lutterbeck
}

Since late 2010, an unprecedented wave of protests has swept across much of the Arab world. In Tunisia, Egypt and Libya long-standing autocrats have been toppled by massive popular uprisings (in the latter case with decisive foreign military support), and in other countries of the region seemingly well-established authoritarian regimes appear increasingly shaky in the face of growing opposition movements. The aim of this paper is to examine the role of the armed forces when confronted with anti-regime uprisings that demand greater political freedoms or even regime change. While armed forces have been key actors in these Arab revolutions, they have responded quite differently across the region to pro-democracy movements, ranging from openness to protest movements, internal fracturing and firm support for the regime in power. This paper argues that these divergent approaches can be explained with reference to different forms of civil-military relations and characteristics of the military apparatus. It argues in particular that the degree of institutionalisation of the armed forces and their relationship to society at large can account for different responses to pro-reform uprisings. This argument is illustrated with six case studies: Tunisia, Egypt, Libya, Bahrain, Yemen and Syria.

Derek Lutterbeck is deputy director and holder of the Swiss Chair at the Mediterranean Academy of Diplomatic Studies in Malta and a project partner of the Research Division within the Geneva Centre for the Democratic Control of Armed Forces (DCAF). He holds a $\mathrm{PhD}$ in political science from the Graduate Institute of International and Development Studies in Geneva. His recent publications have appeared in Mediterranean Politics, the Journal of North African Studies, Contemporary Security Policy, Mediterranean Quarterly, Cooperation and Conflict, European Security, the European Journal of International Relations and Sicherheit und Frieden.

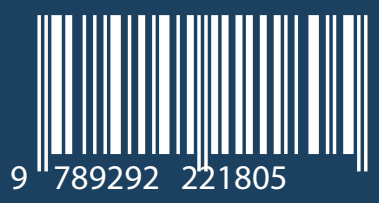

published by DCAF (Geneva Centre for the Democratic Control of Armed Forces)

PO Box 1361

1211 Geneva 1

Switzerland

www.dcaf.ch 